OPEN ACCESS

Edited by:

Alexei Tepikin,

University of Liverpool,

United Kingdom

Reviewed by:

Kazi Mirajul Hoque,

University of Maryland School of

Medicine, Baltimore, United States

Michael Chvanov,

University of Liverpool,

United Kingdom

*Correspondence:

Viktória Venglovecz

venglovecz.viktoria@med.u-szeged.hu

tThese authors have contributed equally to this work

Specialty section:

This article was submitted to Gastrointestinal Sciences, a section of the journal

Frontiers in Physiology

Received: 11 May 2020

Accepted: 25 June 2020

Published: 16 July 2020

Citation:

Becskeházi E, Korsós MM,

Eröss $B$, Hegyi $P$ and Venglovecz $V$

(2020) OEsophageal Ion Transport Mechanisms and Significance Under

Pathological Conditions.

Front. Physiol. 11:855.

doi: 10.3389/fphys.2020.00855

\section{OEsophageal Ion Transport Mechanisms and Significance Under Pathological Conditions}

\author{
Eszter Becskeházi ${ }^{1 \dagger}$, Marietta Margaréta Korsós ${ }^{1 \dagger}$, Bálint Eröss² ${ }^{2}$ Péter Hegyi ${ }^{2,3,4}$ and \\ Viktória Venglovecz ${ }^{1 *}$
}

' Department of Pharmacology and Pharmacotherapy, University of Szeged, Szeged, Hungary, ${ }^{2}$ Institute for Translational Medicine, Szentágothai Research Centre, Medical School, University of Pécs, Pécs, Hungary, ${ }^{3}$ Division of Gastroenterology, First Department of Medicine, Medical School, University of Pécs, Pécs, Hungary, ${ }^{4}$ First Department of Medicine, University of Szeged, Szeged, Hungary

Ion transporters play an important role in several physiological functions, such as cell volume regulation, $\mathrm{pH}$ homeostasis and secretion. In the oesophagus, ion transport proteins are part of the epithelial resistance, a mechanism which protects the oesophagus against reflux-induced damage. A change in the function or expression of ion transporters has significance in the development or neoplastic progression of Barrett's oesophagus (BO). In this review, we discuss the physiological and pathophysiological roles of ion transporters in the oesophagus, highlighting transport proteins which serve as therapeutic targets or prognostic markers in eosinophilic oesophagitis, BO and esophageal cancer. We believe that this review highlights important relationships which might contribute to a better understanding of the pathomechanisms of esophageal diseases.

Keywords: ion transport, oesophagus, Barrett oesophagus, eosinophilic oesophagus, oesophageal cancer

\section{INTRODUCTION}

Ion and water transport play a crucial role in the development of gastrointestinal (GI) diseases, such as cystic fibrosis or diarrhea. Therefore, a number of studies have been conducted to identify the presence and function of transport proteins on GI cells, especially in exocrine glands, the stomach and the colon (Toth-Molnar et al., 2007; Venglovecz et al., 2008, 2011; Farkas et al., 2011; Hegyi et al., 2011; Czepan et al., 2012; Judak et al., 2014) both under physiological and pathophysiological conditions. In contrast, the literature on ion transport in the oesophagus is limited. The oesophageal epithelium (OE) is built up from squamous epithelial cells (SECs) arranged in stratified layers. Although the $\mathrm{OE}$ is not a typical secretory epithelium, its ion transport processes are of great importance with regard to epithelial resistance (Orlando, 1986; Goldstein et al., 1994; Gunther et al., 2014). OE resistance is an important defense mechanism which prevents cells from reflux-induced acidosis (Fujiwara et al., 2005). OE resistance involves a number of factors, such as ion transport processes through apical and basolateral membranes. Disturbances of oesophageal ion transport might play a role in certain pathological conditions, such as eosinophilic oesophagitis (EoO), Barrett's oesophagus (BO) and oesophageal cancer (OC). This review summarizes our knowledge of the expression and function of oesophageal ion transporters and elucidates their role in oesophageal diseases. We believe that this review highlights important relationships which might contribute to a better understanding of the pathomechanisms of oesophageal diseases. 


\section{STRUCTURE OF THE OESOPHAGUS}

The oesophagus consists of four layers, namely the mucosa, submucosa, muscularis externa, and adventitia. Epithelial cells are located in the mucosa and submucosa layers. The mucosa layer is composed of squamous epithelial cells arranged in several rows. There are differences in the thickness and keratinization of the mucosa between species (Figure 1). In the oesophagus of rodents, squamous cells are arranged to 4 to 5 layers and are typically keratinised. In humans and pig's oesophagus, squamous cells are located in several layers, up to 10-15, and the cells are not keratinised. The submucosa layer contains connective tissue cells, blood and lymphatic vessels, nerves, and glands. Interestingly, there are no glands in the oesophagus of rodents, while they occur in large numbers in the oesophagus of humans and pigs. The submucosal glands (SMGs) are tubuloacinar glands that occur scattered throughout the submucosa. SMGs secrete mainly mucus, $\mathrm{HCO}_{3}{ }^{-}$and growth factors, and their primary function is to lubricate the oesophagus and to protect it from the damaging effects of the refluxed acid. The submucosa layer is followed by the muscular externa that is composed of smooth and striated muscle, while adventitia is mostly composed of connective and adipose tissue. Ion mechanisms on SECs have been primarily studied in rabbit, whereas pigs proved to be a suitable animal model for studying ion transport processes associated with SMGs. The next section describes the ion transporters so far identified on SECs and SMGs.

\section{PRESENCE AND ROLE OF ION TRANSPORTERS UNDER PHYSIOLOGICAL CONDITIONS}

\section{$\mathrm{Cl}^{-}$Channels}

Chloride $\left(\mathrm{Cl}^{-}\right)$transport is essentially a two-step process that involves the entry of $\mathrm{Cl}^{-}$into the cell across the basolateral membrane and its secretion into the lumen through the apical membrane (Frizzell and Hanrahan, 2012). These processes involve various transport proteins, of which $\mathrm{Cl}^{-}$ is usually taken up by cells through the $\mathrm{Na}^{+} / \mathrm{K}^{+} / 2 \mathrm{Cl}^{-}$cotransporter (NKCC) and released to the lumen through the cystic fibrosis transmembrane conductance regulator (CFTR). Epithelial $\mathrm{Cl}^{-}$transport provides an electrical driving force for the paracellular transport of $\mathrm{Na}^{+}$from the basolateral side to the lumen. As a result, the osmotic pressure in the lumen increases, which promotes the movement of water into the lumen (Frizzell and Hanrahan, 2012). Oesophageal $\mathrm{Cl}^{-}$ transport in the squamous epithelium and SMGs was mainly investigated by Abdulnour-Nakhoul et al. (2002) (Tables 1, 2). Using isolated rabbit OE, they showed the presence of $\mathrm{Cl}^{-}$ conductance at both the basolateral and the apical membrane of oesophageal epithelial cells (OECs) (Abdulnour-Nakhoul et al., 2002). The basolateral $\mathrm{Cl}^{-}$conductance was $\mathrm{Ca}^{2+}$-dependent and flufenamate-sensitive. However, the CFTR activator, cyclic adenosine monophosphate (cAMP), or the anion exchanger (AE) inhibitor, 4,4'-diisothiocyano-2,2'-stilbenedisulfonic acid
(DIDS), did not affect $\mathrm{Cl}^{-}$conductance. In addition, $\mathrm{Cl}^{-}$ transport was independent of the presence of extracellular $\mathrm{HCO}_{3}{ }^{-}$, indicating that basolateral $\mathrm{Cl}^{-}$conductance is believed to be a $\mathrm{Ca}^{2+}$-activated $\mathrm{Cl}^{-}$channel $(\mathrm{CaCC})$. In contrast, apical $\mathrm{Cl}^{-}$conductance played only a minor role in $\mathrm{Cl}^{-}$transport indicating that there is no significant transcellular $\mathrm{Cl}^{-}$transport across squamous cells. Transcellular $\mathrm{Cl}^{-}$transport has greater importance in SMGs, where fluid secretion is more significant. Apical $\mathrm{Cl}^{-}$transport in SMGs can be linked to the CFTR $\mathrm{Cl}^{-}$channel (Abdulnour-Nakhoul et al., 2011). Using different approaches, the CFTR has been detected in the acinar cells and at the apical membrane of intra- and interlobular ductal cells of pig oesophageal SMGs. In addition, using different activators and inhibitors it has been demonstrated that the CFTR $\mathrm{Cl}^{-}$channel is functionally active and is expected to be involved in $\mathrm{HCO}_{3}{ }^{-}$ secretion in two ways: the CFTR (i) changes its permeability and secretes $\mathrm{HCO}_{3}{ }^{-}$directly into the lumen and (ii) provides extracellular $\mathrm{Cl}^{-}$for the function of the apical $\mathrm{Cl}^{-} / \mathrm{HCO}_{3}{ }^{-}$ exchanger, similarly, to the pancreas or the salivary gland (Lee et al., 2012). The transcellular transport of $\mathrm{Cl}^{-}$is mediated by the basolateral AE2, through which $\mathrm{Cl}^{-}$enters the cell.

\section{$\mathrm{K}^{+}$Channels}

Potassium $\left(\mathrm{K}^{+}\right)$channels have an extensive family, which includes voltage-dependent $\mathrm{K}^{+}$channels, $\mathrm{Ca}^{2+}$-activated $\mathrm{K}^{+}$ channels, or ATP-regulated $\mathrm{K}^{+}$channels (Heitzmann and Warth, 2008). Epithelial $\mathrm{K}^{+}$channels can be found on both the basolateral and luminal membranes of the epithelial cells where they serve different functions. Voltage-dependent $\mathrm{K}^{+}$channels are usually expressed on the basolateral membrane, where they determine the membrane potential of the cell, provide an electrochemical driving force for the transport of other ions, such as $\mathrm{Na}^{+}$or $\mathrm{Cl}^{-}$and also play a role in the recycling of $\mathrm{K}^{+}$ or the regulation of cell volume (Cotton, 2000). $\mathrm{K}^{+}$channels on the apical membrane mediate the secretion of $\mathrm{K}^{+}$into the lumen and therefore determine the $\mathrm{K}^{+}$concentration of the secreted fluid. Using chamber studies have shown the presence of $\mathrm{K}^{+}$conductance at the basolateral membrane of rabbit OECs (Goldstein et al., 1993; Khalbuss et al., 1993). The $\mathrm{K}^{+}$channel is active under basal conditions and regulates transepithelial $\mathrm{Na}^{+}$uptake and cell volume after osmotic stress. The basolateral $\mathrm{K}^{+}$channel has also been shown to be important in regulatory volume decrease (RVD) in isolated rabbit oesophageal cells and human OECs (Snow et al., 1993; Orlando et al., 2002). RVD plays role in the restitution of cell volume after an osmotic swelling. In most cases, $\mathrm{RVD}$ is mediated through the efflux of $\mathrm{K}^{+}$and $\mathrm{Cl}^{-}$ through the basolateral membrane, followed by water transport. Snow et al. (1993) confirmed the significance of $\mathrm{K}^{+}$efflux in RVD and also showed that acidic $\mathrm{pH}$ inhibits $\mathrm{K}^{+}$channel activity, indicating that reduced RVD is probably involved in the refluxinduced oesophageal injury. In addition, using pharmacological inhibitors (e.g., DIDS and diphenylamine-2-carboxylate) or intracellular $\mathrm{Cl}^{-}$removal, the authors showed that RVD also depends on $\mathrm{Cl}^{-}$efflux (Snow et al., 1993). Orlando et al. (2002) made similar observations in human oesophageal cells, with the difference that they also identified a later, second mechanism 


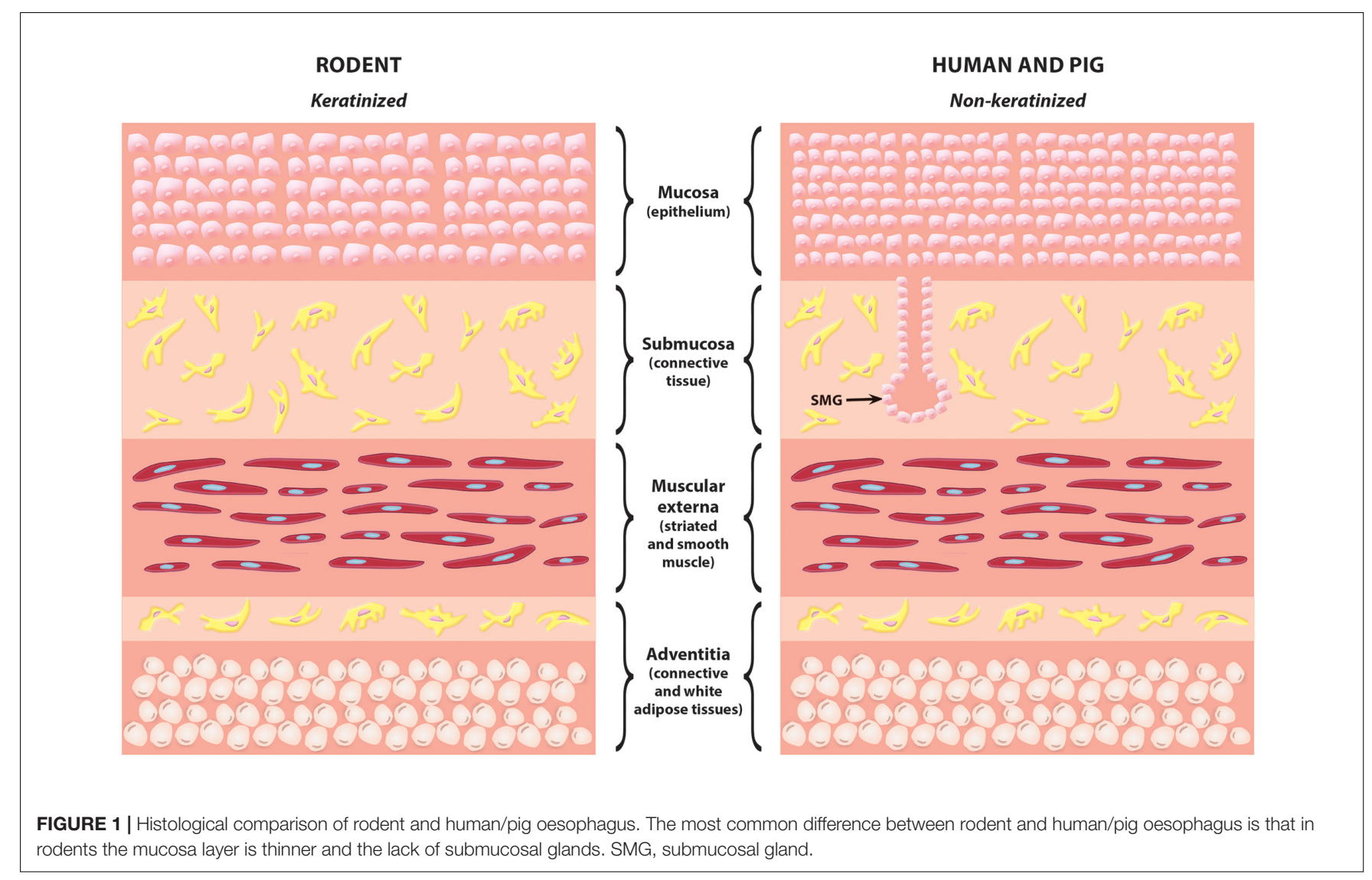

underlying RVD regulation: using $\mathrm{R}(+)$-butylindazone, a $\mathrm{KCl}$ cotransporter (KCC) inhibitor, they detected late RVD inhibition (Orlando et al., 2002). KCC is an electroneutral transporter that mediates the coupled transport of $1 \mathrm{~K}^{+}$and $1 \mathrm{Cl}^{-}$for which the energy is provided by the $\mathrm{K}^{+}$gradient maintained by the $\mathrm{Na}^{+} / \mathrm{K}^{+}$ATPase pump (Haas and Forbush, 1998, 2000). The KCC family has four isoforms (KCC1-4) which show high levels of homology in their amino acid sequence. Although KCC1 ubiquitously expressed, the presence of KCC2 and -3 mainly limited to the nervous system. Abnormal regulation of KCC genes leads to the development of hematological diseases such as sickle cell anemia, which causes cellular dehydration in red blood cells (Rees et al., 2015). In the oesophagus, $\mathrm{K}^{+}$and $\mathrm{Cl}^{-}$transport across the basolateral membrane of SECs present a protective mechanism by which cells try to maintain the cell volume against hypo-osmotic shock under acidic $\mathrm{pH}$ which has a significance in reflux disease (Table $\mathbf{1}$ ).

\section{$\mathrm{Na}^{+} / \mathrm{K}^{+} / 2 \mathrm{Cl}^{-}$Co-Transporter}

The $\mathrm{Na}^{+} / \mathrm{K}^{+} / 2 \mathrm{Cl}^{-}$co-transporter (NKCC) mediates the electroneutral uptake of $1 \mathrm{Na}^{+}, 1 \mathrm{~K}^{+}$and $2 \mathrm{Cl}^{-}$ions across the plasma membrane (Russell, 2000). The NKCC has two isoforms in humans (NKCC1 and NKCC2), which are encoded by two different genes (SLC12A1 and SLC12A2). The NKCC is primarily located on the basolateral membrane of various cells and plays a role in several physiological functions, such as fluid secretion in exocrine glands (Haas and Forbush, 2000) smooth muscle cell contraction (Akar et al., 2001) and early neuronal development (Ben-Ari et al., 2007). In most cells, NKCC interacts with KCC. The effect of the two transporters is opposite. KCC mediates $\mathrm{Cl}^{-}$efflux, whereas NKCC promotes the uptake of $\mathrm{Cl}^{-}$. The coordinated operation of the two transporters ensures the proper $\mathrm{Cl}^{-}$concentration in the cell. NKCC activity is greatly influenced by intracellular $\mathrm{Cl}^{-}$concentration, which acts as a negative feedback mechanism (Rocha-Gonzalez et al., 2008). The mechanism by which cytoplasmic $\mathrm{Cl}^{-}$regulates NKCC is not fully understood, but probably $\mathrm{Cl}^{-}$is able to modify the phosphorylated state of the cotransporter. Loss of function mutations of NKCC2 leads to the development of type 1 Bartter's syndrome, in which the reabsorption of salt is reduced in the thick ascending limb of Henle's loop (Castrop and Schiessl, 2014). In oesophageal SECs, the NKCC is primarily involved in cell volume regulation (Tobey et al., 1995). Functional studies on rabbit $\mathrm{OE}$ have shown that bumetanide-sensitive $\mathrm{Na}^{+} / \mathrm{K}^{+} / \mathrm{Cl}^{-}$transport is activated by acidic $\mathrm{pH}$, is linked to the NKCC and induces cell oedema by ion uptake (Tobey et al., 1995). $\mathrm{K}^{+}$and $\mathrm{Cl}^{-}$conductances work in opposite directions and promote cell shrinkage. NKCC1 is present in the human oesophagus, in the lower and middle layers of squamous cells (Shiozaki et al., 2014a). The NKCC is also present in SMGs, where it plays an essential role in fluid secretion (AbdulnourNakhoul et al., 2011). Immunostaining of pig oesophagus shows strong, positive staining against NKCC1 antibody on the basolateral membrane of mucous cells and interlobular 
TABLE 1 | Expression of ion transporters in oesophageal squamous epithelial cells (SECs).

\begin{tabular}{|c|c|c|c|c|c|}
\hline \multicolumn{6}{|c|}{ Ion transporters in oesophageal squamous epithelial cells (SECs) } \\
\hline Family & Type or isoform & Physiological role & Localization & Species & References \\
\hline $\mathrm{Cl}^{-}$channel & $\mathrm{CaCC}$ & $\begin{array}{l}\text { Regulates intracellular } \mathrm{Cl}^{-} \\
\text {concentration }\end{array}$ & Basolateral & Rabbit & Abdulnour-Nakhoul et al., 2002 \\
\hline \multirow[t]{2}{*}{$\mathrm{K}^{+}$channel } & $\mathrm{N} / \mathrm{A}$ & $\begin{array}{l}\text { Regulates transepithelial } \mathrm{Na}^{+} \text {uptake } \\
\text { and cell volume and also modulates } \\
\text { RVD by } \mathrm{K}^{+} \text {efflux }\end{array}$ & Basolateral & Rabbit & $\begin{array}{l}\text { Goldstein et al., 1993; Khalbuss et al., } \\
\text { 1993; Snow et al., } 1993\end{array}$ \\
\hline & & & & Human & Orlando et al., 2002 \\
\hline $\mathrm{KCC}$ & $\mathrm{N} / \mathrm{A}$ & $\begin{array}{l}\text { Secondary regulatory mechanism of } \\
\text { RVD }\end{array}$ & Basolateral & Human & Orlando et al., 2002 \\
\hline NKCC & NKCC1 & $\begin{array}{l}\text { Operates at acidic } \mathrm{pH} \text { and regulates } \\
\text { cell volume }\end{array}$ & $\mathrm{N} / \mathrm{A}$ & Rabbit & Tobey et al., 1995 \\
\hline \multirow[t]{3}{*}{$\mathrm{NHE}$} & NHE1 & $\begin{array}{l}\text { Causes cellular alkalisation by extruding } \\
\mathrm{H}^{+} \text {out of the cells }\end{array}$ & Basolateral & Rabbit & $\begin{array}{l}\text { Powell et al., 1975; Layden et al., 1990, } \\
\text { 1992; Abdulnour-Nakhoul et al., 1999; } \\
\text { Shallat et al., } 1995\end{array}$ \\
\hline & & & & Rat & Shallat et al., 1995 \\
\hline & & & & Human & $\begin{array}{l}\text { Goldman et al., 2010; Guan et al., } \\
\text { 2014; Laczko et al., 2016; Ariyoshi } \\
\text { et al., } 2017\end{array}$ \\
\hline \multirow[t]{2}{*}{$A E$} & $\mathrm{Na}^{+}$-dependent & $\begin{array}{l}\text { Causes cell alkalisation, mediates } \mathrm{Na}^{+} \text {, } \\
\mathrm{Cl}^{-} \text {and } \mathrm{HCO}_{3}{ }^{-} \text {transport through the } \\
\text { plasma membrane }\end{array}$ & Basolateral & Rabbit & $\begin{array}{l}\text { Bonar and Casey, 2008; Tobey et al., } \\
1993\end{array}$ \\
\hline & $\mathrm{Na}^{+}$-independent & $\begin{array}{l}\text { Causes cell acidification, mediates } \mathrm{Cl}^{-} \\
\text {and } \mathrm{HCO}_{3}{ }^{-} \text {transport through the } \\
\text { plasma membrane }\end{array}$ & & & \\
\hline non-selective cation channel & $\mathrm{ENaC}(?)$ & $\begin{array}{l}\text { Equally permeable for monovalent } \\
\text { cations }\left(\mathrm{Li}^{+}, \mathrm{Na}^{+} \text {and } \mathrm{K}^{+}\right) \text {, the exact } \\
\text { role is not known }\end{array}$ & Apical & Rabbit & Awayda et al., 2004 \\
\hline
\end{tabular}

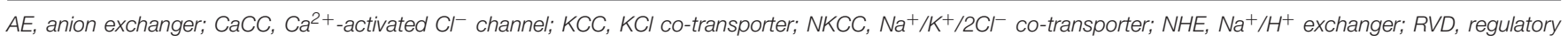
volume decrease; N/A, not available.

TABLE 2 | Expression of ion transporters in oesophageal submucosal glands (SMGs).

lon transporters in oesophageal submucosal glands (SMGs)

\begin{tabular}{|c|c|c|c|c|c|}
\hline Family & Type or isoform & Physiological role & Localization & Species & References \\
\hline $\mathrm{Cl}^{-}$channel & CFTR & Contributes to luminal $\mathrm{HCO}_{3}-$ secretion & Apical & Pig & Abdulnour-Nakhoul et al., 2011 \\
\hline NKCC & NKCC1 & Regulates cell volume and provides $\mathrm{Cl}^{-}$for $\mathrm{HCO}_{3}{ }^{-}$secretion & Basolateral & & \\
\hline \multirow[t]{2}{*}{$\mathrm{AE}$} & AE2 & Facilitates the influx of $\mathrm{Cl}^{-}$and the efflux of $\mathrm{HCO}_{3}{ }^{-}$ & Basolateral & & \\
\hline & SLC26A6 & Mediates $\mathrm{HCO}_{3}-$ transport into the lumen & Apical & & \\
\hline NBC & NBC1 & Contributes to luminal $\mathrm{HCO}_{3}-$ transport & Basolateral & & Abdulnour-Nakhoul et al., 2005, 2011 \\
\hline
\end{tabular}

AE, anion exchanger; CFTR, cystic fibrosis transmembrane conductance regulator; $\mathrm{NBC}, \mathrm{Na}^{+} / \mathrm{HCO}_{3}{ }^{-} \mathrm{co}^{- \text {transporter; }} \mathrm{NKCC}, \mathrm{Na}^{+} / \mathrm{K}^{+} / 2 \mathrm{Cl} \mathrm{CO}^{-}$-transporter.

ducts. Bumetanide, a specific NKCC1 inhibitor, inhibits $\mathrm{HCO}_{3}{ }^{-}$ secretion, indicating that $\mathrm{NKCC1}$ is involved in the process, presumably by providing the $\mathrm{Cl}^{-}$necessary for $\mathrm{HCO}_{3}{ }^{-}$secretion (Abdulnour-Nakhoul et al., 2011).

\section{$\mathrm{Na}^{+} / \mathrm{H}^{+}$Exchangers}

$\mathrm{Na}^{+} / \mathrm{H}^{+}$exchangers (NHEs) are electroneutral exchangers with a stoichiometry of $1 \mathrm{Na}^{+}: 1 \mathrm{H}^{+}$. For the transport of $\mathrm{Na}^{+}$and $\mathrm{H}^{+}$, NHEs use the energy that is provided by the electrochemical $\mathrm{Na}^{+}$ gradient maintained by the $\mathrm{Na}^{+} / \mathrm{K}^{+}$-ATPase. The $\mathrm{N}$-terminal membrane domain of the exchanger is responsible for the transport of ions, whereas NHE is regulated through the C-terminal cytoplasmic domain (Slepkov et al., 2007). NHEs are involved in a wide range of biological functions, such as cell proliferation (Grinstein et al., 1989) cell migration (Denker et al., 2000) and cell volume regulation (Demaurex and Grinstein, 1994). One of their most important roles is cell alkalisation via mediating the exchange of intracellular $\mathrm{H}^{+}$for extracellular $\mathrm{Na}^{+}$. Excess $\mathrm{Na}^{+}$is removed from the cell by the $\mathrm{Na}^{+} / \mathrm{K}^{+}$ATPase and $\mathrm{Na}^{+} / \mathrm{Ca}^{2+}$ exchanger (Slepkov et al., 2007). NHEs are encoded by the SLC9A gene family, which includes nine members (NHE1-NHE9). NHE1 is ubiquitously expressed, while the other isoforms are restricted to a specific tissue. Abnormal function of NHEs is associated with a number of neurological and cardiac diseases (Donowitz et al., 2013). Most NHEs are activated by acidification (Lacroix et al., 2004) and can be blocked 
by amiloride (Kleyman and Cragoe, 1988). Early micro-electrode studies on rabbit oesophagus have described an amiloridesensitive short-circuit current at the serosal and mucosal sides of the oesophagus (Powell et al., 1975). Subsequently, the presence of a $\mathrm{Na}^{+} / \mathrm{H}^{+}$exchange mechanism was proved by Layden et al. (1990). They identified a $\mathrm{Na}^{+}$-dependent, alkalizing transport system in rabbit oesophageal cells which was sensitive to amiloride and was activated at physiological $\mathrm{pH}$ ranges (Layden et al., 1990). Further functional studies have confirmed the presence of NHEs in rabbits (Layden et al., 1992; AbdulnourNakhoul et al., 1999) and humans (Tobey et al., 1998) where $\mathrm{pH}_{\mathrm{i}}$ regeneration depends on extracellular $\mathrm{Na}^{+}$and occurs through the basolateral membrane (Abdulnour-Nakhoul et al., 1999). Reverse transcription-polymerase chain reaction (RT-PCR) and immunoblot analysis confirm the presence of NHE1 in rat and rabbit oesophageal cells (Shallat et al., 1995). Taken together these data suggest that NHE1 is present on the basolateral membrane of rodent oesophageal cells, where it is likely to regulate the $\mathrm{pH}_{\mathrm{i}}$ and protect cells against reflux-induced acidity by extruding $\mathrm{H}^{+}$out of the cells. In contrast, results on NHE1 expression and function in humans are somewhat contradictory. Immunohistochemical (IHC) studies on human oesophageal tissue specimens have shown the absence or weak expression of NHE1 in normal squamous mucosa (Goldman et al., 2010; Guan et al., 2014; Laczko et al., 2016; Ariyoshi et al., 2017), while functional assays performed on the human oesophageal cell line and primary cultures detect a high degree of NHE activity (Tobey et al., 1998; Fujiwara et al., 2005). Even if NHE is present on OECs under normal conditions, the role of NHE in the oesophagus is much more important under pathological conditions as detailed below.

\section{$\mathrm{Cl}^{-} / \mathrm{HCO}_{3}{ }^{-}$Exchangers and $\mathrm{Na}^{+} / \mathrm{HCO}_{3}{ }^{-}$ Co-Transporters}

$\mathrm{Cl}^{-} / \mathrm{HCO}_{3}{ }^{-}$exchangers or AEs mediate $\mathrm{Cl}^{-}$and $\mathrm{HCO}_{3}{ }^{-}$ transport through the plasma membrane (Bonar and Casey, 2008). AEs either alkalise or acidify cells, depending on the direction of $\mathrm{HCO}_{3}{ }^{-}$transport. The AE family comprises a large number of transporters, which are encoded by two gene families (SLC4A and SLC26A) (Bonar and Casey, 2008). The SLC4A family comprises three transporter types: $\mathrm{Na}^{+} / \mathrm{HCO}_{3}{ }^{-}$cotransporters (NBCs), $\mathrm{Na}^{+}$-dependent $\mathrm{Cl}^{-} / \mathrm{HCO}_{3}{ }^{-}$exchangers (NDCBE and NCBE) and $\mathrm{Na}^{+}$-independent $\mathrm{Cl}^{-} / \mathrm{HCO}_{3}{ }^{-}$ exchangers (AE1, AE2, and AE3). Five members of the SLC26A family (SLC26A3, SLC26A4, SLC26A6, SLC26A7, and SLC26A9) differ most in their different $\mathrm{Cl}^{-}: \mathrm{HCO}_{3}{ }^{-}$stoichiometry and therefore in their electrogenicity. AE family members differ in many aspects, such as tissue expression, cell surface localization and physiological function. Abnormal expression of SLC26A2-4 genes associated with rare, recessive diseases, such as diastrophic dysplasia, congenital chloride diarrhea or Pendred syndrome, respectively (Kere, 2006).

Two types of AE are found in oesophageal SECs (Tobey et al., 1993): a $\mathrm{Na}^{+}$-dependent $\mathrm{AE}$ and $\mathrm{a} \mathrm{Na}^{+}$-independent $\mathrm{Cl}^{-} / \mathrm{HCO}_{3}{ }^{-}$exchanger. Although both transporters are electroneutral, their effects are opposite. The $\mathrm{Na}^{+}$-dependent AE plays an important role in cell alkalisation, along with the
NHE, while the $\mathrm{Na}^{+}$-independent $\mathrm{AE}$ acidifies cells, preventing over-alkalisation. $\mathrm{Na}^{+}$-independent AEs mediate the exchange of $1 \mathrm{Cl}^{-}$for $1 \mathrm{HCO}_{3}^{-}$, while $\mathrm{Na}^{+}$-dependent AEs transport $\mathrm{Na}^{+}$, in addition to $\mathrm{HCO}_{3}{ }^{-}$and $\mathrm{Cl}^{-}$. Both $\mathrm{Na}^{+}$-dependent and $\mathrm{Na}^{+}$-independent AEs localize to the basolateral membrane and conduct $\mathrm{HCO}_{3}{ }^{-}$transport from or toward the blood (Layden et al., 1992; Tobey et al., 1993). Oesophageal $\mathrm{HCO}_{3}{ }^{-}$secretion is much more related to SMGs (Abdulnour-Nakhoul et al., 2005, 2011). A basal and carbachol-stimulated movement of $\mathrm{HCO}_{3}{ }^{-}$was detected which was inhibited by DIDS in perfused pig oesophagus. IHC staining showed the presence of an NBC and AE2 on intra- and interlobular ducts and serous demilunes, indicating that $\mathrm{HCO}_{3}{ }^{-}$secretion is probably due to these two transporters. These transporters are localized to the basolateral membrane of ductal cells, and they presumably provide $\mathrm{HCO}_{3}{ }^{-}$ and $\mathrm{Cl}^{-}$for luminal $\mathrm{HCO}_{3}{ }^{-}$secretion (Abdulnour-Nakhoul et al., 2011). In contrast, at the luminal membrane of interlobular ducts, studies have shown the messenger RNA (mRNA) and protein expression of Slc26A6, which mediate $\mathrm{HCO}_{3}{ }^{-}$transport into the lumen, in cooperation with the $\mathrm{CFTR} \mathrm{Cl}^{-}$channel (Abdulnour-Nakhoul et al., 2011). Luminal $\mathrm{HCO}_{3}{ }^{-}$secretion is believed to protect the ooesophagus by neutralizing the acidic refluxate.

\section{Other Ion Transporters}

Awayda et al. (2004) identified non-selective cation conductance at the apical membrane of rabbit OECs which is equally permeable to monovalent cations, such as $\mathrm{Li}^{+}, \mathrm{Na}^{+}$, and $\mathrm{K}^{+}$ (Awayda et al., 2004). In addition, western blotting showed that this non-selective cation channel contains all three subgroups of the epithelial $\mathrm{Na}$ channel $(\mathrm{ENaC})$, in both native rabbit OE and HET-1A cells, although it does not have the characteristics of epithelial $\mathrm{Na}^{+}$channels and is not inhibited by amiloride. The ENaC mediates cation uptake, although its exact function is unknown. In addition, similarly, to other epithelial cells, the $\mathrm{Na}^{+}$gradient across the basolateral membrane is maintained by $\mathrm{Na}^{+} / \mathrm{K}^{+}$-ATPase whose presence has been detected on both squamous cells (Orlando et al., 1981, 1984) and on the basolateral membrane of acini and ductal cells of SMGs (Abdulnour-Nakhoul et al., 2011).

Figure 2 shows the presence and localization of ion transporters on rabbit SECs (Figure 2A) and pig SMGs (Figure 2B). In the case of SECs, transporters are mainly localized to the basolateral membrane, and their primary role is to increase the resistance of these cells to acidic reflux by restoring changes in cell volume and intracellular $\mathrm{pH}$. In contrast, apical and basolateral ion transporters on SMGs are primarily involved in $\mathrm{HCO}_{3}{ }^{-}$secretion, which is secreted into the lumen via the SLC26a6 AE on the apical membrane of intra-interlobular ducts. The secreted $\mathrm{HCO}_{3}{ }^{-}$neutralizes the acidic gastric contents thereby largely prevents the diffusion of the proton into the oesophageal tissue. In conclusion, under physiological conditions, ion transport processes through the SECs and SMGs represent an important defense mechanism that protects the lower layers against the harmful effect of acidic GI contents. Inadequate or altered function of these 
A

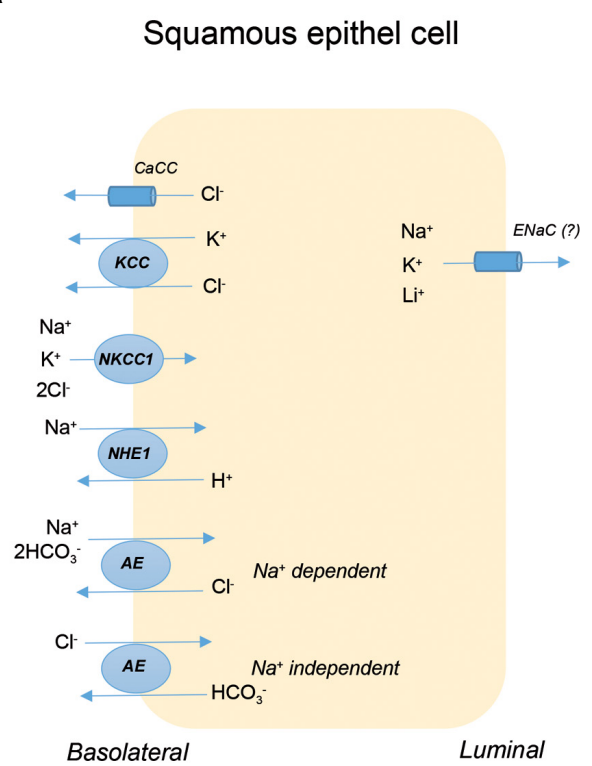

B

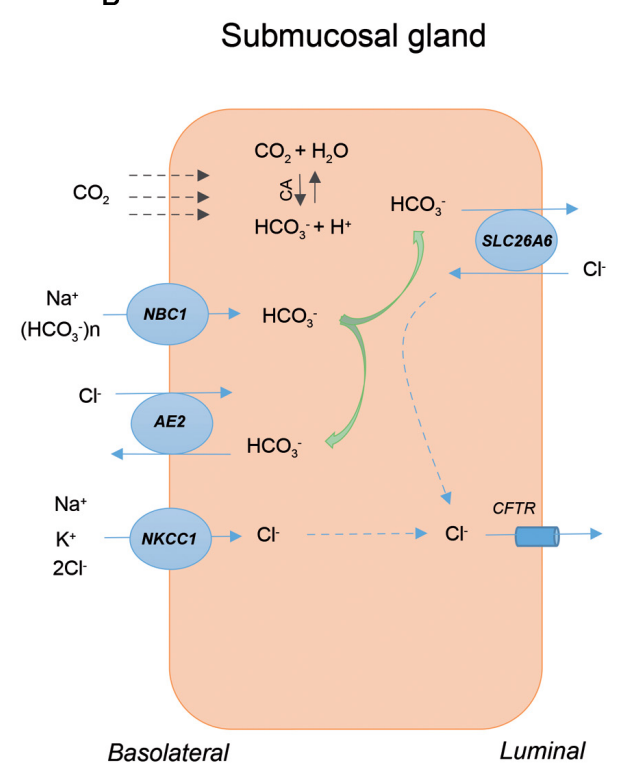

FIGURE 2 | The presence and localization of ion transporters on squamous epithelial cells (SECs) and submucosal glands (SMGs). The schematic diagram shows a rabbit SEC (A) and a ductal cell of pig SMG (B). AE, anion exchanger; CA, carbonic anhydrase; $\mathrm{CaCC}, \mathrm{Ca}^{2+}$-activated $\mathrm{Cl}^{-}$channel; $\mathrm{CFTR}$, cystic fibrosis transmembrane conductance regulator; $\mathrm{KCC}, \mathrm{KCl}$ co-transporter; $\mathrm{NBC}, \mathrm{Na}^{+} / \mathrm{HCO}_{3}{ }^{-}$co-transporter; $\mathrm{NHE}, \mathrm{Na}^{+} / \mathrm{H}^{+}$exchanger; $\mathrm{NKCC}, \mathrm{Na}^{+} / \mathrm{K}^{+} / 2 \mathrm{Cl}{ }^{-}$co-transporter

transporters plays a role in the development and/or progression of oesophageal diseases, such as EoE, BO or OC.

\section{ROLE OF ION TRANSPORTERS UNDER PATHOLOGICAL CONDITIONS}

\section{Eosinophilic Oesophagitis}

Eosinophilic oesophagitis is a chronic inflammatory disease induced by food antigens (Furuta and Katzka, 2015). EoE is characterized by basal zone hyperplasia $(\mathrm{BZH})$, dilated intercellular spaces (DISs) and the filtration of eosinophilic granulocytes into the oesophageal mucosa (Collins, 2008). Interleukin 13 (IL-13) plays a major role in EoE pathology. IL-13 is highly up-regulated in inflamed tissue and regulates the expression of several key molecules (Blanchard et al., 2010). Studies have reported altered expression of two ion transporters [NHE3 and anoctamin 1 (ANO1)] in EoE (Zeng et al., 2018; Vanoni et al., 2020). The mRNA and protein expression of both NHE3 and ANO1 significantly increases in biopsy samples obtained from EoE patients and in IL-13treated OECs and model systems. Both NHE3 and ANO1 are up-regulated by the transcription factor signal transducer and activator of transcription 6 (STAT6) and are positively correlated with disease progression (Zeng et al., 2018; Vanoni et al., 2020). Pharmacological NHE3 inhibition blocks IL-13-induced DIS formation, indicating the involvement of NHE3 in DIS formation (Zeng et al., 2018). NHE3 mediates the exchange of intracellular $\mathrm{H}^{+}$with extracellular $\mathrm{Na}^{+}$. Proton accumulation in the intercellular space creates osmotic conditions which favor water transport and, as a result, DIS formation (Zeng et al., 2018).
In contrast to NHE3, increased ANO1 expression is associated with BZH (Vanoni et al., 2020). ANO1 is an apical $\mathrm{Ca}^{2+}$. activated $\mathrm{Cl}^{-}$channel which is also permeable to $\mathrm{HCO} 3-$ (Jung et al., 2013). Application of ANO1 inhibitor or short hairpin RNA (shRNA) shows that this $\mathrm{Cl}^{-}$channel interacts with cell cycle regulatory proteins, such as TP63 and phosphorylated cyclin-dependent kinase 2 (p-CDK2), thereby enhancing cell proliferation. In addition, $\mathrm{Cl}^{-}$efflux through ANO1 likely plays a role in intracellular $\mathrm{Cl}^{-}$depletion, which is a prerequisite for cell division. These results indicate that both NHE3 and ANO1 are part of the IL-13-mediated transcriptional cascade, which leads to the histopathological features of EoE. Therefore, inhibition of these transporters could be a potential therapeutic target for EoE treatment (Vanoni et al., 2020).

\section{Gastro-Oesophageal Reflux Disease and Barrett's Oesophagus}

Barrett's oesophagus is a condition in which the normal squamous epithelium is replaced by columnar cells (Spechler and Souza, 2014). It is the result of long-term gastro-oesophageal reflux disease (GERD) and a type of adaptation to the altered environment (Spechler and Souza, 2014). Many factors play a role in $\mathrm{BO}$ development, although the exact underlying mechanism is unclear. Several studies have been conducted in which normal epithelial cells were exposed to acidic $\mathrm{pH}$, bile acids or a combination of the two and molecular changes and cell survival were investigated. Lin et al. (2008) identified DIDSand ethyl-isopropyl amiloride (EIPA)-sensitive and $\mathrm{HCO}_{3}{ }^{-}$dependent transport mechanisms in rat oesophageal tissue upon $\mathrm{HCl}$ administration, indicating the involvement of an NHE and 
one of the SLC26 AEs in the stimulatory effect of $\mathrm{HCl}$ (Lin et al., 2008). Increased ionic movement due to acid exposure is likely a protective mechanism and might play a role in the GERD pathomechanism. Acidic $\mathrm{pH}$ decreases cell viability and increases reactive oxygen species production in normal OECs, in which NHE1 plays a protective role (Park et al., 2015). Similar results have been found in human oesophageal cell lines, in which the cytoprotective effect of epidermal growth factor against acid-induced cell damage is mediated by NHE1 through the $\mathrm{Ca}^{2+} /$ calmodulin and protein kinase $\mathrm{C}(\mathrm{PKC})$ pathway (Fujiwara et al., 2005). Increased NHE1 expression is found in oesophagitis, GERD and BO, although it is unclear whether increased NHE1 levels are the consequence or the cause of these diseases (Siddique and Khan, 2003; Fujiwara et al., 2005; Goldman et al., 2010; Laczko et al., 2016). According to Siddique and Khan (2003) NHE1 is involved in GERD development, presumably by acidifying the extracellular space (Siddique and Khan, 2003). The authors also found that in patients taking $\mathrm{H} 2$ receptor blockers, the mRNA level of NHE1 is significantly lower compared to untreated or antacid-treated GERD patients, assuming a specific interaction between NHE1 and the histamine receptor in GERD. In contrast, the increased NHE1 expression in BO is more likely part of a defense or adaptive mechanism which protects cells against acid reflux (Goldman et al., 2010). This hypothesis is also supported by another study in which bile treatment alone or in combination with acid increased NHE1 expression in metaplastic (CP-A) and dysplastic (CP-D) oesophageal cell lines (Laczko et al., 2016). Interestingly, NHE activity decreased in CP-A as a result of treatment but increased in CP-D cells in a dosedependent manner. The reason probably is that CP-D cells are in a more advanced state and are more frequently exposed to acid or biliary reflux under pathological conditions. In addition to NHE1, NHE2, NBC, and Slc26a6 expression also increased in intestinal and non-intestinal metaplasia, which probably further enhances cellular resistance against reflux-induced cell damage (Laczko et al., 2016). These results suggest that increased NHE expression found in $\mathrm{BO}$ is essentially a defense mechanism by which metaplastic tissue tries to adapt to the altered environment. Inhibition of the transporter promotes tumorigenesis because of a decrease in intracellular $\mathrm{pH}$.

Transient receptor potential channels (TRP) is a multifamily of integral membrane proteins that found on several tissues and cell types in animals (Nilius and Owsianik, 2011). TRP channels function as non-selective cation channels and are permeable to $\mathrm{Na}^{+} ; \mathrm{Ca}^{2+}$ and $\mathrm{Mg}^{2}$. The TRP family can be subdivided into seven subfamilies: TRPC (canonical), TRPV (vanilloid), TRPM (melastatin), TRPP (polycystin), TRPML (mucolipin), TRPA (ankyrin), and TRPN (NOMPC-like). These channels mediate a wide range of physiological functions, such as sensations of temperature, pain, tastes, vision, olfaction, hearing and intracellular ion homeostasis. Some TRP channels act as a thermo-; osmolarity- or voltage sensor, and some of them activated by membrane stretch or cytoplasm volume changes. The activated TRP channels cause depolarisation of the cell membranes, which is essential in the development of action potential in excitable cells (Nilius and Owsianik, 2011). The role of the TRP channels in the non-excitable cells is mostly to mediate the ion homeostasis of the cells (Yu et al., 2016). TRPV1 acts as molecular acid sensor in the oesophagus which activated by acidosis ( $\mathrm{pH}$ level under 6) (Holzer, 2008). TRPV1 is overexpressed in the oesophageal mucosa of patients with non-erosive reflux disease (NERD) and erosive esophagitis and also in animal models of NERD (Guarino et al., 2010; Silva et al., 2018). Increased levels of TRPV1 was also observed in stress-induced oesophageal inflammation (Wulamu et al., 2019). The role of TRPV1 in inflammation can be explained by the fact that activation of the channel promotes the secretion of inflammatory mediators (platelet-activating factor (PAF), Il- 1 $\beta$, Il-6) that initiates the inflammatory cascade in the mucosa of the oesophagus. Therefore, inhibition of TRPV1 could be beneficial in inflammatory conditions. Recently, Zhang et al. have shown that menthol inhibits acid-induced inflammation by inhibiting TRPV1 expression and TRPV1-mediated $\mathrm{Ca}^{2+}$ influx in oesophageal epithelial cells (Zhang et al., 2020). TRPV4 is also a non-selective cation channel activated by mechanical, thermal, and chemical stimuli. Acid-sensitive TRPV4 channels are mainly expressed in the epithelial cells of the basal and intermediate layers of the oesophagus (Shikano et al., 2011). Ueda et al. showed the presence of TRPV4 in human oesophageal biopsy samples and HET-1A cell line. They demonstrated that activation of TRPV4 increases intracellular $\mathrm{Ca}^{2+}$ level and decreases Il-8 production that plays a role in different cellular functions, such as cell division or viability (Ueda et al., 2011). The presence of functionally active TRPV4 has also been shown in mouse oesophageal keratinocytes, where activation of the channel caused ATP release which affects the sensory nerves and might also be related to the pathophysiology of NERD (Mihara et al., 2011; Suzuki et al., 2015).

\section{Oesophageal Cancer}

Oesophageal cancer is a malignant neoplasm, and the sixthleading cause of cancer-related death worldwide (Klingelhofer et al., 2019). The two most common types of OC are oesophageal squamous cell carcinoma (ESCC) and oesophageal adenocarcinoma (EAC) (Enzinger and Mayer, 2003). Current treatment of OC includes surgery, chemo- or radiotherapy or the combination of the three. Although OC treatment and diagnosis have advanced, the 5-year survival rate is between 15 and 20\% and recurrence is frequent (Shapiro et al., 2015). Therefore, there is an urgent need to develop new therapies that can complement existing treatments or allow individual therapies. Disturbances of ion transport processes are considered to be of great importance in cancer research (Pedersen and Stock, 2013; Djamgoz et al., 2014; Oosterwijk and Gillies, 2014; Stock and Schwab, 2015; Martial, 2016). Ion transporters are not only involved in tumorigenesis by altering the membrane permeability of certain ions, but some transporters interact with other signaling molecules (kinases, transcription factors) that influence the cell cycle or the metastatic potential of the cells. In recent years, several transporters and ion channels have been identified whose expression is altered in OC. In the following, those ion transporters are discussed, that might provide a target point for novel treatment or serve as prognostic markers for ESCC or EAC (Supplementary Table S1). 


\section{$\mathrm{K}^{+}$Channels}

Ding et al. (2008a,b) identified two voltage-gated $\mathrm{K}^{+}$channels, Eag1 (KV10.1, KCNH1) and hERG1 (KV11.1, KCNH2), which are aberrantly expressed in ESCC and are correlated with poor prognosis (Ding et al., 2008a,b). Human ether a-go-go-related gene 1 ( $h E R G 1$ ) over-expression has been found in $\mathrm{BO}$ and even more in dysplasia and adenocarcinoma, indicating that $h E R G 1$ expression increases during BO progression to EAC (Lastraioli et al., 2006). To support this observation, Lastraioli et al. (2016) conducted a comprehensive study on hERG1 expression in both mice and humans. The authors found increased $h E R G 1$ expression in two different $\mathrm{BO}$ mice models. They also found that surgically induced $\mathrm{BO}$ more frequently develops in mice with $h E R G 1$ over-expression. The significance of hERG1 in BO progression to EAC has also been demonstrated in human biopsy samples obtained from $\mathrm{BO}$ patients. Using monoclonal antibody against hERG1, the 10-year follow-up showed that BO patients with increased hERG1 expression have a higher risk of EAC development, indicating that hERG1 can be used as a biomarker to predict disease progression (Lastraioli et al., 2016).

\section{Inhibitors and Therapeutic Perspectives}

Potassium channel blockers are most commonly used as antiarrhythmic agents, however, research in recent years has shown that there is a growing need for $\mathrm{K}^{+}$channel inhibitors in cancer therapy as well. Currently, AZD9291 is used in the treatment of non-small cell lung cancer (Janne et al., 2015). AZD9291 is an epidermal growth factor receptor (EGFR) tyrosine kinase inhibitor (TKI) that is able to inhibit hERG channels. Another EGFR TKI, gefitinib has also been proved to be effective in non-small cell lung cancer patients and has shown to be beneficial in breast cancer as well (Garcia-Quiroz et al., 2019). Experimental data demonstrated that gefitinib dose-dependently inhibited the proliferation of cancer cells and combined administration of this drug with the antihistamine, astemizole resulted in a synergistic effect (Garcia-Quiroz et al., 2019). Although the two EGFR TKIs inhibit different channels, AZD9291 is specific for hERG channel, while gefitinib for Eag1, they have similar mechanisms of action, both of them prevent the channel phosphorylation which is required for the activation of the channels (Zhang et al., 2008; Wu et al., 2012).

\section{ANO1}

Shang et al. (2016) reported a correlation between anoctamin1 (ANO1) expression and primary oesophageal tumor in two independent cohorts. The authors detected strong ANO1 staining in the tumor region of surgical specimens obtained from ESCC patients, while the adjacent normal tissue and endoscopic biopsies from normal mucosa and chronic oesophagitis were completely negative for this $\mathrm{Cl}^{-}$channel (Shang et al., 2016). In addition, ANO1 expression is correlated with the malignant progression of precancerous oesophageal lesions, indicating that ANO1 can be used as a biomarker to predict disease progression. Shi et al. (2009) identified genes whose expression is altered in ESCC and dysplasia. They found increased ANO1 levels at both mRNA and protein levels in ESCC and dysplastic samples. In addition, they found a correlation between ANO1 expression and tumor progression (Shi et al., 2004). Interestingly, in the mRNA expression of ANO1, the authors found no significant difference between normal mucosa and oesophagitis (Shi et al., 2009) although Vanoni et al. (2020) have shown increased ANO1 expression in EoE. Genetic inhibition of ANO1 decreases proliferation in ESCC cell lines, confirming the role of ANO1 in cell division. The mechanism underlying ANO1-induced promotion of cell proliferation is unclear, although, in head and neck squamous cell carcinoma, activation of the mitogenactivated protein kinase (MAPK)/extracellular signal-regulated kinase (ERK) signaling pathway is involved in the proliferative effect of ANO1 (Duvvuri et al., 2012).

\section{Inhibitors and Therapeutic Perspectives}

Several inhibitors are known that can inhibit ANO1 with greater or lesser potency or selectivity, such as the small molecule inhibitor, Ani9 (Seo et al., 2016) the benzofuran derivative, benzbromarone (Huang et al., 2012), the flavonoid, luteolin (Seo et al., 2017) the aminophenylthiazole, [T16A(inh)-A01] or the arylaminothiophene, CaCC(inh)-A01 (Namkung et al., 2011). Among them, luteolin has been shown as potential anticancer therapeutic agents for the treatment of prostate cancer (Seo et al., 2017). This inhibitor not only blocks ANO1 activity but also decreases its protein expression. Using PC-3, prostate cancer cell line, administration of luteolin reduced the proliferation and migration of the cells (Seo et al., 2017). Similar results were observed with Ani9, T16A(inh)-A01 and CaCC(inh)A01 inhibitors, which also reduced PC-3 cell proliferation and induced apoptosis, by a TNF- $\alpha$-mediated signaling pathway (Song et al., 2018). ANO1 inhibitors have also been shown to be beneficial in ovarian cancer, where administration of LY294002 reduced the growth of cancer cells by inhibiting the PI3K/Akt signaling pathway (Liu et al., 2019). The mechanism of action of ANO1 inhibitors is not yet known, and there is no evidence to date that it has been used in the treatment of inflammatory or cancerous diseases of the oesophagus, but it could be a promising target.

\section{AEs}

Shiozaki et al. (2017) characterized the role of AE1 and AE2 in ESCC tumorigenesis. Analysis of ESCC samples showed that the AE1 staining intensity depends on the tumor length, while the focal or diffuse distribution of AE1 is correlated with the histological type and pT stage (Shiozaki et al., 2017). With regard to 5-year survival, the staining score was not correlated with prognosis, although diffuse AE1 expression was associated with poor survival in advanced stages (Shiozaki et al., 2017). AE1 expression has been found in ESCC cell lines (TE5, TE8, TE9, and KYSE150), where it is involved in cell cycle regulation and the proliferation, apoptosis, migration and invasion of ESCC cells via the MAPK and Hedgehog signaling pathways (Shiozaki et al., 2017). In contrast to AE1, decreased AE2 expression is associated with poor prognosis in ESCC patients (Shiozaki et al., 2018). There is a correlation between the AE2 staining score and the $\mathrm{pT}$ stage. With regard to survival, low AE2 expression predicts a worse prognosis. Interestingly, these correlations were observed only in the invasive front of ESCC, 
not in the entire tumor. In contrast to AE1, AE2 expression was found in KYSE170, and TE13 ESCC cell lines and AE2 knock-down decreased apoptosis and increased migration and invasion of ESCC cells, indicating that AE2 regulates cell survival and cellular movements. Studies have also demonstrated that the effect of AE2 is mediated by matrix metalloproteinases (MMPs) and their inhibitors. Altered AE2 expression is believed to affect tumorigenesis by altering intracellular $\mathrm{pH}$. Decreased AE2 expression favors intracellular alkalisation, which promotes cancer cell metabolism (Persi et al., 2018).

\section{Inhibitors and Therapeutic Perspectives}

The most commonly used inhibitors of anion transporters are the stilbene derivatives, DIDS, its reduced form dihydroDIDS (H2DIDS) and 4-acetamido-4'-isothiocyanatostilbene-2,2' disulfonic acid (SITS). The negatively charged sulfonate group of these inhibitors interact electrostatically with the anion binding site of the transporter, resulting in a rapid, reversible inhibition, followed by a slower covalent interaction between the isothiocyanate group of the inhibitor and the free amino acids of the AE. These inhibitors have low specificity and inhibit individual isoforms with different potency (Humphreys et al., 1994; Alper et al., 1998). There are also differences in the efficacy of inhibitors between species and cell types. The oxonol dye, diBA(5)C4 has been shown to inhibit the AE1 isoform more effectively than AE2, while polyaminosterols have higher selectivity to AE2 (Alper et al., 1998). Among the more recently discovered AE inhibitors, 4,8-dimethyl-7-( $m$-bromobenzyloxy)coumarin-3-acetic acid has been shown to be able to completely and selectively inhibit the SLC26A3 exchanger, and the use of this agent showed a beneficial effect on constipation in a mouse model (Lee et al., 2019) although, to our knowledge, there is currently no AE inhibitor which enters or underwent in clinical trials.

\section{KCC3 and NKCC1}

Among KCC isoforms, KCC3 expression is associated with OC tumorigenesis (Shiozaki et al., 2014b). The presence of KCC3 in the invasive front of ESCC is associated with a low survival rate post-operatively. The mechanism underlying KCC3's effect on tumor progression is unclear, but studies using ESCC cell lines have shown that KCC3 is essential for the invasiveness of cancer cells (Shiozaki et al., 2014b). NKCC1 is also a biomarker in ESCC. NKCC1 expression is closely related to the differentiation of ESCC cells, and genetic or pharmacologic inhibition of NKCC1 in ESCC cell lines significantly decreases the rate of cell proliferation, indicating that NKCC1 is involved in cell cycle regulation (Shiozaki et al., 2014a).

\section{Inhibitors and Therapeutic Perspectives}

The loop diuretics, bumetanide and furosemide, are the most commonly used inhibitors of NKCCs. Both inhibitors are able to inhibit the co-transporter even at very low concentrations (0.5$5 \mu \mathrm{M})$. Diuretics have long been used to treat fluid retention, and in recent years their use has also emerged in the treatment of certain neurological disorders. Therefore, several clinical studies have been conducted to test the effect of bumetanide in schizophrenia, epilepsy or Parkinson's disease (Ben-Ari, 2017). Although, the clinical use of this inhibitor is limited due to its ionized state at physiological $\mathrm{pH}$ and its high binding to plasma proteins. Recent studies suggest that azosemide is more potent than bumetanide and has better pharmacokinetic properties (Hampel et al., 2018). Bumetanide and furosemide at higher concentrations (100 $\mu \mathrm{M}-1 \mathrm{mM})$ inhibit KCCs as well. In addition, KCC also sensitive to DIDS, H2DIDS, and SITS, although the inhibitory effect of these stilbene derivatives highly depends on external $\mathrm{K}^{+}$(Delpire and Lauf, 1992). Currently, the most commonly used KCC inhibitor is dihydroindenyloxy alkanoic acid (DIOA), which selectively inhibits the transporter. The large-scale high-throughput screen on HEK293 cells identified more potent inhibitors, such as ML077 or VU0463271, (Delpire and Weaver, 2016) although none of these compounds is currently under clinical development.

\section{NHE}

Among ion transporters, the expression of NHEs, especially NHE1, alters in a metaplasia-dysplasia-adenocarcinoma sequence. Recent studies have demonstrated that NHE1 also plays a significant role in BO progression to EAC. Fitzgerald et al. (1998) showed that NHE1 is involved in acid-induced cell proliferation in BO biopsy samples in a PKC-dependent manner (Fitzgerald et al., 1998). The cell proliferation-inducing effect of NHE1 is explained by increased NHE1 activity at acidic $\mathrm{pH}$, which likely affects cell division by altering intracellular $\mathrm{pH}$. In contrast, bile acids alone or in combination with acid decrease NHE1 activity in nitric oxide- and nitric oxide synthasedependent manner in BO-derived CP-A cells, leading to cellular acidosis (Goldman et al., 2010). The decrease in intracellular $\mathrm{pH}$ favors DNA damage, which increases the incidence of mutations and, therefore, the risk of EAC progression (Goldman et al., 2010). However, this workgroup also showed that bile acid damages lysosomes as well in JH-EsoAd1 and CP-A cells and the acidic content released from them increases NHE activity, which forms an ionic environment that favors to apoptotic processes. Based on these findings, it is hypothesized that by the inhibition of NHE, the cells avoid apoptosis, increasing the risk of cancer transformation (Goldman et al., 2011). The role of NHE1 in OC is contradictory. Guan et al. (2014) have shown that NHE1 is over-expressed in EAC and inhibition of NHE1 expression or blocking of NHE activity by amiloride decreases cancer cell proliferation and induces apoptosis in both EAC and ESCC cell lines and in nude mice xenografts. Moreover, amiloride in combination with guggulsterone (antagonist of frasenoid $\mathrm{X}$ receptor) proved to be even more effective than amiloride alone. These results indicate that contrast to metaplastic cells, inhibition of NHE does not enhance tumor progression but, on the contrary, inhibits it, suggesting that NHE behaves differently in cancerous and metaplastic cells. In contrast, Ariyoshi et al. (2017) found that NHE1 inhibition favors the proliferation, migration and invasion of ESCC cells because of the up-regulation of epithelial-mesenchymal transformation (EMT) markers and the inhibition of Notch signaling. The 5-year overall survival (OS) was significantly higher in ESCC patients 
with high NHE1 expression, indicating the possibility of using NHE1 as a prognostic marker (Ariyoshi et al., 2017).

\section{Inhibitors and Therapeutic Perspectives}

The most commonly used NHE1 inhibitors are amiloride and its derivatives such as EIPA (5-( $\mathrm{N}$-ethyl- $\mathrm{N}$-isopropyl) amiloride), DMA (5-(N,N-dimethyl) amiloride) and HMA (5-(N,N-hexamethylene) amiloride) that belongs to the pyrazinoylguanidine-type inhibitors, as well as the more specific cariporide and epripride that belongs to the benzoylguanidinetype inhibitors (Rolver et al., 2020). In the case of both types of inhibitors, guanidine binds to the sodium binding site of the exchanger, thereby competes with the sodium for the binding site (Frelin et al., 1986). Numerous studies have suggested the use of NHE inhibitors in the treatment of various types of cancer, such as breast or colon cancer (Miraglia et al., 2005; Rolver et al., 2020), however, clinical evaluation of NHE inhibitors is currently limited to cardiac disease, particularly in connection with ischemia-reperfusion injury, in which the cardioprotective effect of cariporide and eniporide was demonstrated in two clinical trials (Chaitman, 2003; Mentzer et al., 2008).

\section{$\mathrm{Ca}^{2+}$ Channels}

Orai-1 is the pore-forming subunit of the calcium-release activated channel. By interacting with the $\mathrm{Ca}^{2+}$ sensor stromal interaction molecule 1 (STIM-1), Orai-1 mediates store-operated $\mathrm{Ca}^{2+}$ entry (SOCE). Orai-1 is involved in tumorigenesis in many cancer types, including OC (Vashisht et al., 2015). Zhu et al. (2014) reported increased Orai-1 expression in tumor tissues obtained from ESCC patients. The Orai-1 expression is correlated with clinicopathological features, such as histological grade, T-stage classification and lymph node metastasis, and poor OS and recurrence-free survival rates. Increased Orai-1 expression and intense oscillatory $\mathrm{Ca}^{2+}$ activities are also found in ESCC cell lines, which probably plays a role in carcinogenesis. The role of Orai-1 in tumorigenesis has been confirmed using cell-based assays in which Orai-1 knock-down decreased the proliferation, migration and invasion of ESCC cells and tumor growth in nude mice xenografts (Zhu et al., 2014). The proliferative effect of Orai-1 might be inhibited by zinc, which selectively interacts with the histidine residue of Orai- 1 and inhibits SOCE and $\mathrm{Ca}^{2+}$ oscillations in ESCC cells (Choi et al., 2018). RP4010, a specific Orai-1 inhibitor, also inhibits tumor growth via an unknown mechanism and is a potential therapeutic or adjuvant drug for ESCC treatment (Cui et al., 2018). The role of voltage-gated $\mathrm{Ca}^{2+}$ channels has also been raised in relation to OC. Voltage-gated calcium channels are comprised of heteromultimeric complexes that involve $\alpha 1$ protein in combination with various auxiliary subunits, $\beta, \alpha 2 \delta$, and $\gamma$ protein (Walker and De Waard, 1998). Four $\alpha 2 \delta$ subunit genes have been identified (CACNA2D14) (Qin et al., 2002). The $\alpha 2 \delta-3$ subunit (CACNA2D3) is responsible for $\mathrm{Ca}^{2+}$ influx, and its tumor suppressor function was also characterized. It has been shown, that CACNA2D3 induces apoptosis, reduces cell motility, and provokes cell cycle arrest in G1 phase through transactivating p53/p21 signaling pathways (Lipskaia and Lompre, 2004;Li et al., 2013). The potential tumor suppressor role of CACNA2D3 in the pathomechanism of malignancies has been mentioned in several studies. Considering the GI tract, the promoter methylation of this gene is in association with poor prognosis of gastric cancer (Wanajo et al., 2008). Li et al. showed that downregulation of CACNA2D3 could be detected in ESCC patients that showed a positive correlation with a poor progression and low overall survival rate (Li et al., 2013). A recent study indicates, that overexpression of CACNA2D3 can restore chemosensitivity of ESCC cells to cisplatin via inhibition of PI3K/Akt pathway, which is a promising finding regarding the therapy of ESCC (Nie et al., 2019).

TRPC6 proteins are non-selective cation channels, which are permeable to cations $\left(\mathrm{Ca}^{2+}, \mathrm{Na}{ }^{+}, \mathrm{K}^{+}, \mathrm{Cs}^{+}\right.$and $\left.\mathrm{Ba}^{2+}\right)$ iron, zinc and N-methyl-D-glucamine (Bouron et al., 2016). TRPC6 seems to be ubiquitous in the human body and involved in the regulation of intracellular $\mathrm{Ca}^{2+}$ concentration (Hofmann et al., 2000). There are several activators of the TRPC6 channels, such as extracellular $\mathrm{Ca}^{2+}$ concentration,(Shi et al., 2004) diacylglycerol (DAG) and its analogs, such as 1-oleoyl2-acetyl-sn-glycerol, and arachidonic acids (Aires et al., 2007) and hyperforin (Leuner et al., 2007). Literature data indicate that TRPC6 is associated with tumorigenesis, tumor growth and elevated TRPC6 expression was detected in many cancer types (Santoni and Farfariello, 2011). It has been reported that TRPC6 expression significantly higher in ESCC patients, and it correlates with poor progression (Shi et al., 2009; Zhang et al., 2013). Shi et al. have shown, that inhibition of TRPC6 resulted in cell cycle arrest at G2 phase, reduced cell growth in ESCC cells and the formation of tumor in nude mice (Shi et al., 2009). Evaluating this finding (Ding et al., 2010) have raised the possibility that inhibition of TRPC6 can increase the radiosensitivity of tumor cells and also inhibits angiogenesis in the therapy of ESCC. Similar results have been found by Zhang et al. Using an ESCC cell line, Eca109 they showed that administration of the TRPC inhibitor, SKF96365 arrested the cell cycle at G2/M phase, and in combination with radiation it significantly reduced in vitro cell proliferation and the tumor size in nude mice (Zhang et al., 2017).

The role of TRPVs has arisen primarily in the inflammatory diseases of the oesophagus (GERD, NERD); although Huang et al. have also shown its importance in ESCC (Huang et al., 2019). They found that both TRPV 1 and -4 are up-regulated in ESCC, and overactivation of these channels can modulate the proliferation and migration of ESCC cells, by the regulation of intracellular $\mathrm{Ca}^{2+}$ concentration (Huang et al., 2019).

\section{Inhibitors and Therapeutic Perspectives}

$\mathrm{Ca}^{2+}$ channels are aberrantly regulated in most of the cancer cells; therefore, great efforts are made to develop novel drugs that are able to modulate the function of these channels. Inhibition of $\mathrm{Ca}^{2+}$ channels is a promising target in cancer therapy, and there are $\mathrm{Ca}^{2+}$ channel blockers that have already undergone clinical trials or are under clinical development. The specific Orai-1 inhibitor, RP4010 completed a Phase I/Ib clinical trial in which the safety and efficacy of RP4010 were evaluated in lymphoma. In addition, RP4010 significantly reduced cell division, especially in combination with anticancer agents in pancreatic ductal adenocarcinoma (Khan et al., 2020). 
The recently identified SOR-C13 is an inhibitor of TRPV6 channels that selectively binds to the channel and prevents the influx of $\mathrm{Ca}^{2+}$ into the cells. SOR-C13 has been shown to be effective in ovarian cancer (Xue et al., 2018) and is currently undergoing Phase I clinical trials to determine the best dose and side effect profile of this drug, in advanced refractory solid tumors.

\section{Aquaporins}

Ion movement is accompanied by water movement. Transcellular water transport is mediated by aquaporins (AQPs). The main driving force of AQPs is the osmotic difference between the intraand the extracellular space. In addition to water transport, AQPs are involved in the transport of smaller molecules or function as ion channels. Several mechanisms have been described through which AQPs enhance tumor cell migration and invasion (De Ieso and Yool, 2018). AQP1 facilitates hypoxia-induced angiogenesis, AQP1, -3, -4, -5, and -9 are involved in epithelial-mesenchymal transition and extracellular matrix degradation, whereas AQP14 enhance cell adhesion (De Ieso and Yool, 2018). Of the 13 isoforms currently identified, AQP1, -3, -5, and -8 are associated with OC. AQP1 is widely expressed in many tissues and is a potential biomarker in breast cancer (Qin et al., 2016). Yamazato et al. (2018) found a correlation between AQP1 expression and the outcome of ESCC patients (Yamazato et al., 2018). The authors showed that in ESCC patients with high AQP1 expression in the cytoplasm, the 5-year survival rate is lower compared to ESCC patients in whom AQP1 is localized to the nuclear membrane. AQP1 knock-down in ESCC cell lines inhibits cell proliferation and migration and induces apoptosis. In addition, microarray analysis shows an interaction between AQP1 and death-receptor signaling pathway-related genes, supporting the importance of AQP1 in tumorigenesis. Similar results were observed for AQP3 (Kusayama et al., 2011; Niu et al., 2012). AQP3 is highly expressed in ESCC, and the absence or decreased function of AQP3 decreases adhesion of cancerous cells via inhibition of integrins and the focal adhesion kinase-mitogen-activated protein kinase (FAK-MAPK) signaling pathway. Inhibition of cell adhesion is associated with decreased cell growth and apoptosis, indicating the critical role of AQP3 in cell survival. Increased expression of AQP3 in ESCC and EAC has also been demonstrated by Niu et al. (2012). Studies have also reported the importance of AQP5 in ESCC (Shimizu et al., 2014). AQP5 down-regulation inhibits cell cycle progression in ESCC cell lines, and microarray analysis shows that a lack of AQP5 affects the expression of genes involved in cellular growth. Studies have shown a correlation between the size and histological type of ESCC and AQP5 expression in human tumor tissues. In addition, the 3-year progression-free survival is lower in ESCC patients with AQP5 positivity, which raises the possibility of using AQP5 as a biomarker. AQP8 has also been implicated in the progression of OC (Chang et al., 2014). Using human ESCC cell line, Eca-109, it has been shown that the epidermal growth factor (EGF)-induced cell migration is associated with increased expression of AQP8 through the EGF receptor-ERK1/2 signal transduction pathway.

\section{Inhibitors and Therapeutic Perspectives}

Several inhibitors have been identified that are more or less effective in inhibiting AQPs, such as the small molecule inhibitors, TEA and acetazolamide, which can selectively and reversibly inhibit AQP1 and -4 isoforms (Abir-Awan et al., 2019). The recently discovered molecules, DFP00173 and Z433927330 that have been shown to block glyceroporins by reducing channel glycerol permeability (Abir-Awan et al., 2019). Among the heavy metal ions, $\mathrm{Cu}$ ions, $\mathrm{NiCl}_{2}$ and gold compounds proved to be effective in inhibiting AQP3 (Aikman et al., 2018). $\mathrm{HgCl}_{2}$ is also widely used to inhibit AQPs, however, the disadvantage of this molecule is that it blocks all AQP isoforms and mercury is highly toxic to cells due to its many side effects (Aikman et al., 2018). Furthermore, monoclonal antibodies such as antiAQP4 have been shown to be promising agents in the treatment of neuromyelitis optica (NMO) (Tradtrantip et al., 2012) and clinical trials are in progress to evaluate the efficacy of antiAQP4 IgG in NMO and multiple sclerosis. To the best of our knowledge, no controlled clinical trial has been conducted to date in which the effects of AQP inhibitors have been tested in oesophageal diseases.

\section{CONCLUSION}

This review summarized the expression and role of ion transporters in OECs (Tables 1, 2) and described their pathological function (Supplementary Table S1). Ion transport fundamentally determines both the extra- and the intracellular $\mathrm{pH}$, which affects several intracellular mechanisms, including the release of inflammatory mediators or the expression of cell cycle regulatory proteins. Research increasingly highlights the significance of ion transporters in various inflammatory and cancerous processes, and many of them have emerged as promising therapeutic targets or independent prognostic factors in cancer. This review described numerous ion transporters whose inhibition reduces proliferation and induces apoptosis of cancerous oesophageal cells (Supplementary Table S1). These findings raise the possibility that pharmacological inhibition of these ion transporters or a combination of ion transporter inhibitors with chemotherapeutic agents might provide alternative treatment options for OC patients who do not respond to standard treatment.

\section{AUTHOR CONTRIBUTIONS}

$\mathrm{VV}, \mathrm{EB}$, and MK contributed to conception and design of the study. EB and PH wrote separate sections of the manuscript. All authors read and approved the submitted version.

\section{FUNDING}

This study was supported by the National Research, Development and Innovation Office (FK123982), the 
Economic Development and Innovation Operational Programme Grant (GINOP-2.3.2-15-2016-00015), and the National Research, Development and Innovation Office, by the Ministry of Human Capacities (EFOP 3.6.2-162017-00006).

\section{REFERENCES}

Abdulnour-Nakhoul, S., Bor, S., Imeryuz, N., and Orlando, R. C. (1999). Mechanisms of basolateral $\mathrm{Na}+$ transport in rabbit esophageal epithelial cells. Am. J. Physiol. 276, G507-G517.

Abdulnour-Nakhoul, S., Nakhoul, H. N., Kalliny, M. I., Gyftopoulos, A., Rabon, E., Doetjes, R., et al. (2011). Ion transport mechanisms linked to bicarbonate secretion in the esophageal submucosal glands. Am. J. Physiol. Regul. Integr. Comp. Physiol. 301, R83-R96.

Abdulnour-Nakhoul, S., Nakhoul, N. L., Caymaz-Bor, C., and Orlando, R. C. (2002). Chloride transport in rabbit esophageal epithelial cells. Am. J. Physiol. Gastrointest. Liver Physiol. 282, G663-G675.

Abdulnour-Nakhoul, S., Nakhoul, N. L., Wheeler, S. A., Wang, P., Swenson, E. R., and Orlando, R. C. (2005). HCO3- secretion in the esophageal submucosal glands. Am. J. Physiol. Gastrointest. Liver Physiol. 288, G736-G744.

Abir-Awan, M., Kitchen, P., Salman, M. M., Conner, M. T., Conner, A. C., and Bill, R. M. (2019). Inhibitors of mammalian aquaporin water channels. Int. J. Mol. Sci. 20:1589. doi: 10.3390/ijms20071589

Aikman, B., De Almeida, A., Meier-Menches, S. M., and Casini, A. (2018). Aquaporins in cancer development: opportunities for bioinorganic chemistry to contribute novel chemical probes and therapeutic agents. Metallomics 10, 696-712. doi: 10.1039/c8mt00072g

Aires, V., Hichami, A., Boulay, G., and Khan, N. A. (2007). Activation of TRPC6 calcium channels by diacylglycerol (DAG)-containing arachidonic acid: a comparative study with DAG-containing docosahexaenoic acid. Biochimie 89, 926-937. doi: 10.1016/j.biochi.2006.10.016

Akar, F., Jiang, G., Paul, R. J., and O'neill, W. C. (2001). Contractile regulation of the $\mathrm{Na}(+)-\mathrm{K}(+)-2 \mathrm{Cl}(-)$ cotransporter in vascular smooth muscle. Am. J. Physiol. Cell Physiol. 281, C579-C584.

Alper, S. L., Chernova, M. N., Williams, J., Zasloff, M., Law, F. Y., and Knauf, P. A. (1998). Differential inhibition of AE1 and AE2 anion exchangers by oxonol dyes and by novel polyaminosterol analogs of the shark antibiotic squalamine. Biochem. Cell Biol. 76, 799-806. doi: 10.1139/o98-082

Ariyoshi, Y., Shiozaki, A., Ichikawa, D., Shimizu, H., Kosuga, T., Konishi, H., et al. (2017). $\mathrm{Na}+/ \mathrm{H}+$ exchanger 1 has tumor suppressive activity and prognostic value in esophageal squamous cell carcinoma. Oncotarget 8, 2209-2223. doi: 10.18632/oncotarget.13645

Awayda, M. S., Bengrine, A., Tobey, N. A., Stockand, J. D., and Orlando, R. C. (2004). Nonselective cation transport in native esophageal epithelia. Am. J. Physiol. Cell Physiol. 287, C395-C402.

Ben-Ari, Y. (2017). NKCC1 chloride importer antagonists attenuate many neurological and psychiatric disorders. Trends Neurosci. 40, 536-554. doi: 10.1016/j.tins.2017.07.001

Ben-Ari, Y., Gaiarsa, J. L., Tyzio, R., and Khazipov, R. (2007). GABA: a pioneer transmitter that excites immature neurons and generates primitive oscillations. Physiol. Rev. 87, 1215-1284. doi: 10.1152/physrev.00017.2006

Blanchard, C., Stucke, E. M., Burwinkel, K., Caldwell, J. M., Collins, M. H., Ahrens, A., et al. (2010). Coordinate interaction between IL-13 and epithelial differentiation cluster genes in eosinophilic esophagitis. J. Immunol. 184, 40334041. doi: 10.4049/jimmunol.0903069

Bonar, P. T., and Casey, J. R. (2008). Plasma membrane $\mathrm{Cl}(-) / \mathrm{HCO}(3)(-)$ exchangers: structure, mechanism and physiology. Channels 2, 337-345. doi: 10.4161/chan.2.5.6899

Bouron, A., Chauvet, S., Dryer, S., and Rosado, J. A. (2016). Second messengeroperated calcium entry through TRPC6. Adv. Exp. Med. Biol. 898, 201-249. doi: 10.1007/978-3-319-26974-0_10

Castrop, H., and Schiessl, I. M. (2014). Physiology and pathophysiology of the renal Na-K-2Cl cotransporter (NKCC2). Am. J. Physiol. Renal Physiol. 307, F991-F1002.

\section{SUPPLEMENTARY MATERIAL}

The Supplementary Material for this article can be found online at: https://www.frontiersin.org/articles/10.3389/fphys. 2020.00855/full\#supplementary-material

Chaitman, B. R. (2003). A review of the GUARDIAN trial results: clinical implications and the significance of elevated perioperative CK-MB on 6-month survival. J. Card. Surg. 18(Suppl. 1), 13-20. doi: 10.1046/j.1540-8191.18.s1.3.x

Chang, H., Shi, Y. H., Talaf, T. K., and Lin, C. (2014). Aquaporin-8 mediates human esophageal cancer Eca-109 cell migration via the EGFR-Erk1/2 pathway. Int. J. Clin. Exp. Pathol. 7, 7663-7671.

Choi, S., Cui, C., Luo, Y., Kim, S. H., Ko, J. K., Huo, X., et al. (2018). Selective inhibitory effects of zinc on cell proliferation in esophageal squamous cell carcinoma through Orai1. FASEB J. 32, 404-416. doi: 10.1096/fj.201700227rrr

Collins, M. H. (2008). Histopathologic features of eosinophilic esophagitis. Gastrointest. Endosc. Clin. N. Am. 18, 59-71. doi: 10.1016/j.giec.2007. 09.014

Cotton, C. U. (2000). Basolateral potassium channels and epithelial ion transport. Am. J. Respir. Cell Mol. Biol. 23, 270-272. doi: 10.1165/ajrcmb.23.3.f198

Cui, C., Chang, Y., Zhang, X., Choi, S., Tran, H., Penmetsa, K. V., et al. (2018). Targeting Orail-mediated store-operated calcium entry by RP4010 for antitumor activity in esophagus squamous cell carcinoma. Cancer Lett. 432, 169179. doi: 10.1016/j.canlet.2018.06.006

Czepan, M., Rakonczay, Z., Varro, A., Steele, I., Dimaline, R., Lertkowit, N., et al. (2012). NHE1 activity contributes to migration and is necessary for proliferation of human gastric myofibroblasts. Pflugers Arch. 463, 459-475. doi: 10.1007/s00424-011-1059-6

De Ieso, M. L., and Yool, A. J. (2018). Mechanisms of aquaporin-facilitated cancer invasion and metastasis. Front. Chem. 6:135. doi: 10.3389/fchem.2018.00135

Delpire, E., and Lauf, P. K. (1992). Kinetics of DIDS inhibition of swelling-activated K-Cl cotransport in low K sheep erythrocytes. J. Membr. Biol. 126, 89-96.

Delpire, E., and Weaver, C. D. (2016). Challenges of finding novel drugs targeting the K-Cl cotransporter. ACS Chem. Neurosci. 7, 1624-1627. doi: 10.1021/ acschemneuro.6b00366

Demaurex, N., and Grinstein, S. (1994). Na+/H+ antiport: modulation by ATP and role in cell volume regulation. J. Exp. Biol. 196, 389-404.

Denker, S. P., Huang, D. C., Orlowski, J., Furthmayr, H., and Barber, D. L. (2000). Direct binding of the $\mathrm{Na}-\mathrm{H}$ exchanger NHE1 to ERM proteins regulates the cortical cytoskeleton and cell shape independently of $\mathrm{H}(+)$ translocation. Mol. Cell 6, 1425-1436. doi: 10.1016/s1097-2765(00)00139-8

Ding, X., He, Z., Shi, Y., Wang, Q., and Wang, Y. (2010). Targeting TRPC6 channels in oesophageal carcinoma growth. Expert Opin. Ther. Targets 14, 513-527. doi: $10.1517 / 14728221003733602$

Ding, X. W., Luo, H. S., Luo, B., Xu, D. Q., and Gao, S. (2008a). Overexpression of hERG1 in resected esophageal squamous cell carcinomas: a marker for poor prognosis. J. Surg. Oncol. 97, 57-62. doi: 10.1002/jso.20891

Ding, X. W., Wang, X. G., Luo, H. S., Tan, S. Y., Gao, S., Luo, B., et al. (2008b). Expression and prognostic roles of Eagl in resected esophageal squamous cell carcinomas. Dig. Dis. Sci. 53, 2039-2044. doi: 10.1007/s10620-007-0116-7

Djamgoz, M. B., Coombes, R. C., and Schwab, A. (2014). Ion transport and cancer: from initiation to metastasis. Philos. Trans. R. Soc. Lond. B Biol. Sci. 369:20130092. doi: 10.1098/rstb.2013.0092

Donowitz, M., Ming Tse, C., and Fuster, D. (2013). SLC9/NHE gene family, a plasma membrane and organellar family of $\mathrm{Na}(+) / \mathrm{H}(+)$ exchangers. Mol. Aspects Med. 34, 236-251. doi: 10.1016/j.mam.2012.05.001

Duvvuri, U., Shiwarski, D. J., Xiao, D., Bertrand, C., Huang, X., Edinger, R. S., et al. (2012). TMEM16A induces MAPK and contributes directly to tumorigenesis and cancer progression. Cancer Res. 72, 3270-3281. doi: 10.1158/0008-5472. can-12-0475-t

Enzinger, P. C., and Mayer, R. J. (2003). Esophageal cancer. N. Engl. J. Med. 349, 2241-2252.

Farkas, K., Yeruva, S., Rakonczay, Z., Ludolph, L., Molnar, T., Nagy, F., et al. (2011). New therapeutic targets in ulcerative colitis: the importance of ion transporters in the human colon. Inflamm. Bowel Dis. 17, 884-898. doi: 10.1002/ibd.21432 
Fitzgerald, R. C., Omary, M. B., and Triadafilopoulos, G. (1998). Altered sodiumhydrogen exchange activity is a mechanism for acid-induced hyperproliferation in Barrett's esophagus. Am. J. Physiol. 275, G47-G55.

Frelin, C., Vigne, P., Barbry, P., and Lazdunski, M. (1986). Interaction of guanidinium and guanidinium derivatives with the $\mathrm{Na}+/ \mathrm{H}+$ exchange system. Eur. J. Biochem. 154, 241-245. doi: 10.1111/j.1432-1033.1986.tb09388.x

Frizzell, R. A., and Hanrahan, J. W. (2012). Physiology of epithelial chloride and fluid secretion. Cold Spring Harb. Perspect. Med. 2:a009563. doi: 10.1101/ cshperspect.a009563

Fujiwara, Y., Higuchi, K., Tominaga, K., Watanabe, T., Oshitani, N., and Arakawa, T. (2005). Functional oesophageal epithelial defense against acid. Inflammopharmacology 13, 1-13. doi: 10.1163/156856005774423953

Furuta, G. T., and Katzka, D. A. (2015). Eosinophilic Esophagitis. N. Engl. J. Med. 373, 1640-1648.

Garcia-Quiroz, J., Gonzalez-Gonzalez, M. E., Diaz, L., Ordaz-Rosado, D., SegoviaMendoza, M., Prado-Garcia, H., et al. (2019). Astemizole, an inhibitor of Ether-a-Go-Go-1 potassium channel, increases the activity of the tyrosine kinase inhibitor Gefitinib in breast cancer cells. Rev. Invest. Clin. 71, 186-194.

Goldman, A., Chen, H., Khan, M. R., Roesly, H., Hill, K. A., Shahidullah, M., et al. (2011). The $\mathrm{Na}+/ \mathrm{H}+$ exchanger controls deoxycholic acid-induced apoptosis by a $\mathrm{H}+$-activated, $\mathrm{Na}+$-dependent ionic shift in esophageal cells. PLoS One 6:e23835. doi: 10.1371/journal.pone.0023835

Goldman, A., Shahidullah, M., Goldman, D., Khailova, L., Watts, G., Delamere, N., et al. (2010). A novel mechanism of acid and bile acid-induced DNA damage involving $\mathrm{Na}+/ \mathrm{H}+$ exchanger: implication for Barrett's oesophagus. Gut 59, 1606-1616. doi: 10.1136/gut.2010.213686

Goldstein, J. L., Fogelson, B. G., Snow, J. C., Schmidt, L. N., Mozwecz, H., and Layden, T. J. (1993). Rabbit esophageal cells possess K+ channels: effect of hyposmotic stress on channel activity. Gastroenterology 104, 417-426. doi: 10.1016/0016-5085(93)90409-6

Goldstein, J. L., Watkins, J. L., Greager, J. A., and Layden, T. J. (1994). The esophageal mucosal resistance: structure and function of an unique gastrointestinal epithelial barrier. J. Lab. Clin. Med. 123, 653-659.

Grinstein, S., Rotin, D., and Mason, M. J. (1989). Na+/H+ exchange and growth factor-induced cytosolic $\mathrm{pH}$ changes. Role in cellular proliferation. Biochim. Biophys. Acta 988, 73-97. doi: 10.1016/0304-4157(89)90004-x

Guan, B., Hoque, A., and Xu, X. (2014). Amiloride and guggulsterone suppression of esophageal cancer cell growth in vitro and in nude mouse xenografts. Front. Biol. 9, 75-81. doi: 10.1007/s11515-014-1289-z

Guarino, M. P., Cheng, L., Ma, J., Harnett, K., Biancani, P., Altomare, A., et al. (2010). Increased TRPV1 gene expression in esophageal mucosa of patients with non-erosive and erosive reflux disease. Neurogastroenterol. Motil. 22,74651.e219.

Gunther, C., Neumann, H., and Vieth, M. (2014). Esophageal epithelial resistance. Dig. Dis. 32, 6-10. doi: 10.1159/000357001

Haas, M., and Forbush, B. (1998). The Na-K-Cl cotransporters. J. Bioenerg. Biomembr. 30, 161-172.

Haas, M., and Forbush, B. (2000). The Na-K-Cl cotransporter of secretory epithelia. Annu. Rev. Physiol. 62, 515-534. doi: 10.1146/annurev.physiol.62.1.515

Hampel, P., Romermann, K., Macaulay, N., and Loscher, W. (2018). Azosemide is more potent than bumetanide and various other loop diuretics to inhibit the sodium-potassium-chloride-cotransporter human variants hNKCC1A and hNKCC1B. Sci. Rep. 8:9877.

Hegyi, P., Pandol, S., Venglovecz, V., and Rakonczay, Z. Jr. (2011). The acinarductal tango in the pathogenesis of acute pancreatitis. Gut 60, 544-552. doi: 10.1136/gut.2010.218461

Heitzmann, D., and Warth, R. (2008). Physiology and pathophysiology of potassium channels in gastrointestinal epithelia. Physiol. Rev. 88, 1119-1182. doi: 10.1152/physrev.00020.2007

Hofmann, T., Schaefer, M., Schultz, G., and Gudermann, T. (2000). Transient receptor potential channels as molecular substrates of receptor-mediated cation entry. J. Mol. Med. 78, 14-25. doi: 10.1007/s001090050378

Holzer, P. (2008). The pharmacological challenge to tame the transient receptor potential vanilloid-1 (TRPV1) nocisensor. Br. J. Pharmacol. 155, 1145-1162. doi: 10.1038/bjp.2008.351

Huang, F., Zhang, H., Wu, M., Yang, H., Kudo, M., Peters, C. J., et al. (2012). Calcium-activated chloride channel TMEM16A modulates mucin secretion and airway smooth muscle contraction. Proc. Natl. Acad. Sci. U.S.A. 109, 16354-16359. doi: 10.1073/pnas.1214596109

Huang, R., Wang, F., Yang, Y., Ma, W., Lin, Z., Cheng, N., et al. (2019). Recurrent activations of transient receptor potential vanilloid-1 and vanilloid-4 promote cellular proliferation and migration in esophageal squamous cell carcinoma cells. FEBS Open Bio 9, 206-225. doi: 10.1002/2211-5463.12570

Humphreys, B. D., Jiang, L., Chernova, M. N., and Alper, S. L. (1994). Functional characterization and regulation by $\mathrm{pH}$ of murine $\mathrm{AE} 2$ anion exchanger expressed in Xenopus oocytes. Am. J. Physiol. 267, C1295-C1307.

Janne, P. A., Yang, J. C., Kim, D. W., Planchard, D., Ohe, Y., Ramalingam, S. S., et al. (2015). AZD9291 in EGFR inhibitor-resistant non-small-cell lung cancer. N. Engl. J. Med. 372, 1689-1699.

Judak, L., Hegyi, P., Rakonczay, Z., Maleth, J., Gray, M. A., and Venglovecz, V. (2014). Ethanol and its non-oxidative metabolites profoundly inhibit CFTR function in pancreatic epithelial cells which is prevented by ATP supplementation. Pflugers Arch. 466, 549-562. doi: 10.1007/s00424-013-1333$\mathrm{x}$

Jung, J., Nam, J. H., Park, H. W., Oh, U., Yoon, J. H., and Lee, M. G. (2013). Dynamic modulation of ANO1/TMEM16A HCO3(-) permeability by Ca2+/calmodulin. Proc. Natl. Acad. Sci. U.S.A. 110, 360-365. doi: 10.1073/ pnas. 1211594110

Kere, J. (2006). Overview of the SLC26 family and associated diseases. Novartis Found. Symp. 273, 2-11.

Khalbuss, W. E., Alkiek, R., Marousis, C. G., and Orlando, R. C. (1993). Potassium conductance in rabbit esophageal epithelium. Am. J. Physiol. 265, G28-G34.

Khan, H. Y., Mpilla, G. B., Sexton, R., Viswanadha, S., Penmetsa, K. V., Aboukameel, A., et al. (2020). Calcium Release-Activated Calcium (CRAC) channel inhibition suppresses pancreatic ductal adenocarcinoma cell proliferation and patient-derived tumor growth. Cancers 12:750. doi: $10.3390 /$ cancers 12030750

Kleyman, T. R., and Cragoe, E. J. (1988). Amiloride and its analogs as tools in the study of ion transport. J. Membr. Biol. 105, 1-21. doi: 10.1007/bf01871102

Klingelhofer, D., Zhu, Y., Braun, M., Bruggmann, D., Schoffel, N., and Groneberg, D. A. (2019). A world map of esophagus cancer research: a critical accounting. J. Transl. Med. 17:150.

Kusayama, M., Wada, K., Nagata, M., Ishimoto, S., Takahashi, H., Yoneda, M., et al. (2011). Critical role of aquaporin 3 on growth of human esophageal and oral squamous cell carcinoma. Cancer Sci. 102, 1128-1136. doi: 10.1111/j.13497006.2011.01927.x

Lacroix, J., Poet, M., Maehrel, C., and Counillon, L. (2004). A mechanism for the activation of the $\mathrm{Na} / \mathrm{H}$ exchanger NHE-1 by cytoplasmic acidification and mitogens. EMBO Rep. 5, 91-96. doi: 10.1038/sj.embor.7400035

Laczko, D., Rosztoczy, A., Birkas, K., Katona, M., Rakonczay, Z., Tiszlavicz, L., et al. (2016). Role of ion transporters in the bile acid-induced esophageal injury. Am. J. Physiol. Gastrointest. Liver Physiol. 311, G16-G31.

Lastraioli, E., Lottini, T., Iorio, J., Freschi, G., Fazi, M., Duranti, C., et al. (2016). hERG1 behaves as biomarker of progression to adenocarcinoma in Barrett's esophagus and can be exploited for a novel endoscopic surveillance. Oncotarget 7, 59535-59547. doi: 10.18632/oncotarget.11149

Lastraioli, E., Taddei, A., Messerini, L., Comin, C. E., Festini, M., Giannelli, M., et al. (2006). hERG1 channels in human esophagus: evidence for their aberrant expression in the malignant progression of Barrett's esophagus. J. Cell. Physiol. 209, 398-404. doi: 10.1002/jcp.20748

Layden, T. J., Agnone, L. M., Schmidt, L. N., Hakim, B., and Goldstein, J. L. (1990). Rabbit esophageal cells possess an $\mathrm{Na}+, \mathrm{H}+$ antiport. Gastroenterology 99, 909-917. doi: 10.1016/0016-5085(90)90606-2

Layden, T. J., Schmidt, L., Agnone, L., Lisitza, P., Brewer, J., and Goldstein, J. L. (1992). Rabbit esophageal cell cytoplasmic pH regulation: role of $\mathrm{Na}+-\mathrm{H}+$ antiport and $\mathrm{H}+-$ dependent HCO3- transport systems. Am. J. Physiol. 263, G407-G413.

Lee, M. G., Ohana, E., Park, H. W., Yang, D., and Muallem, S. (2012). Molecular mechanism of pancreatic and salivary gland fluid and HCO3 secretion. Physiol. Rev. 92, 39-74. doi: 10.1152/physrev.00011.2011

Lee, S., Cil, O., Haggie, P. M., and Verkman, A. S. (2019). 4,8-Dimethylcoumarin Inhibitors of Intestinal Anion Exchanger slc26a3 (Downregulated in Adenoma) for Anti-Absorptive Therapy of Constipation. J. Med. Chem. 62, 8330-8337. doi: 10.1021/acs.jmedchem.9b01192 
Leuner, K., Kazanski, V., Muller, M., Essin, K., Henke, B., Gollasch, M., et al. (2007). Hyperforin-a key constituent of St. John's wort specifically activates TRPC6 channels. FASEB J. 21, 4101-4111. doi: 10.1096/fj.07-8110com

Li, Y., Zhu, C. L., Nie, C. J., Li, J. C., Zeng, T. T., Zhou, J., et al. (2013). Investigation of tumor suppressing function of CACNA2D3 in esophageal squamous cell carcinoma. PLoS One 8:e60027. doi: 10.1371/journal.pone.0060027

Lin, B. R., Hsieh, H. T., Lee, J. M., Lai, I. R., Chen, C. F., and Yu, L. C. (2008). Luminal hydrochloric acid stimulates rapid transepithelial ion fluxes in rodent esophageal stratified squamous epithelium. J. Physiol. Pharmacol. 59, 525-542.

Lipskaia, L., and Lompre, A. M. (2004). Alteration in temporal kinetics of Ca2+ signaling and control of growth and proliferation. Biol. Cell 96, 55-68. doi: 10.1016/j.biolcel.2003.11.001

Liu, Z., Zhang, S., Hou, F., Zhang, C., Gao, J., and Wang, K. (2019). Inhibition of $\mathrm{Ca}(2+)$-activated chloride channel ANO1 suppresses ovarian cancer through inactivating PI3K/Akt signaling. Int. J. Cancer 144, 2215-2226. doi: 10.1002/ ijc.31887

Martial, S. (2016). Involvement of ion channels and transporters in carcinoma angiogenesis and metastasis. Am. J. Physiol. Cell Physiol. 310, C710-C727.

Mentzer, R. M., Bartels, C., Bolli, R., Boyce, S., Buckberg, G. D., Chaitman, B., et al. (2008). Sodium-hydrogen exchange inhibition by cariporide to reduce the risk of ischemic cardiac events in patients undergoing coronary artery bypass grafting: results of the EXPEDITION study. Ann. Thorac. Surg. 85, 1261-1270. doi: 10.1016/j.athoracsur.2007.10.054

Mihara, H., Boudaka, A., Sugiyama, T., Moriyama, Y., and Tominaga, M. (2011). Transient receptor potential vanilloid 4 (TRPV4)-dependent calcium influx and ATP release in mouse oesophageal keratinocytes. J. Physiol. 589, 3471-3482. doi: 10.1113/jphysiol.2011.207829

Miraglia, E., Viarisio, D., Riganti, C., Costamagna, C., Ghigo, D., and Bosia, A. (2005). Na $+/ \mathrm{H}+$ exchanger activity is increased in doxorubicin-resistant human colon cancer cells and its modulation modifies the sensitivity of the cells to doxorubicin. Int. J. Cancer 115, 924-929. doi: 10.1002/ijc.20959

Namkung, W., Phuan, P. W., and Verkman, A. S. (2011). TMEM16A inhibitors reveal TMEM16A as a minor component of calcium-activated chloride channel conductance in airway and intestinal epithelial cells. J. Biol. Chem. 286, 23652374. doi: 10.1074/jbc.m110.175109

Nie, C., Qin, X., Li, X., Tian, B., Zhao, Y., Jin, Y., et al. (2019). CACNA2D3 enhances the chemosensitivity of esophageal squamous cell carcinoma to cisplatin via inducing $\mathrm{Ca}(2+)$-mediated apoptosis and suppressing PI3K/Akt pathways. Front. Oncol. 9:185. doi: 10.3389/fonc.2019.00185

Nilius, B., and Owsianik, G. (2011). The transient receptor potential family of ion channels. Genome Biol. 12:218. doi: 10.1186/gb-2011-12-3-218

Niu, D., Kondo, T., Nakazawa, T., Yamane, T., Mochizuki, K., Kawasaki, T., et al. (2012). Expression of aquaporin 3 in human neoplastic tissues. Histopathology 61, 543-551. doi: 10.1111/j.1365-2559.2011.04165.x

Oosterwijk, E., and Gillies, R. J. (2014). Targeting ion transport in cancer. Philos. Trans. R. Soc. Lond. B Biol. Sci. 369:20130107. doi: 10.1098/rstb.2013.0107

Orlando, G. S., Tobey, N. A., Wang, P., Abdulnour-Nakhoul, S., and Orlando, R. C. (2002). Regulatory volume decrease in human esophageal epithelial cells. Am. J. Physiol. Gastrointest. Liver Physiol. 283, G932-G937.

Orlando, R. C. (1986). Esophageal epithelial resistance. J. Clin. Gastroenterol. 8(Suppl. 1), 12-16. doi: 10.1097/00004836-19860600100004

Orlando, R. C., Bryson, J. C., and Powell, D. W. (1984). Mechanisms of H+ injury in rabbit esophageal epithelium. Am. J. Physiol. 246, G718-G724.

Orlando, R. C., Powell, D. W., and Carney, C. N. (1981). Pathophysiology of acute acid injury in rabbit esophageal epithelium. J. Clin. Invest. 68, 286-293. doi: $10.1172 /$ jci1 10246

Park, S. Y., Lee, Y. J., Cho, E. J., Shin, C. Y., and Sohn, U. D. (2015). Intrinsic resistance triggered under acid loading within normal esophageal epithelial cells: NHE1- and ROS-mediated survival. J. Cell. Physiol. 230, 1503-1514. doi: $10.1002 /$ jcp. 24896

Pedersen, S. F., and Stock, C. (2013). Ion channels and transporters in cancer: pathophysiology, regulation, and clinical potential. Cancer Res. 73, 1658-1661. doi: 10.1158/0008-5472.can-12-4188

Persi, E., Duran-Frigola, M., Damaghi, M., Roush, W. R., Aloy, P., Cleveland, J. L., et al. (2018). Systems analysis of intracellular $\mathrm{pH}$ vulnerabilities for cancer therapy. Nat. Commun. 9:2997.
Powell, D. W., Morris, S. M., and Boyd, D. D. (1975). Water and electrolyte transport by rabbit esophagus. Am. J. Physiol. 229, 438-443. doi: 10.1152/ ajplegacy.1975.229.2.438

Qin, F., Zhang, H., Shao, Y., Liu, X., Yang, L., Huang, Y., et al. (2016). Expression of aquaporin1, a water channel protein, in cytoplasm is negatively correlated with prognosis of breast cancer patients. Oncotarget 7, 8143-8154. doi: 10.18632/ oncotarget.6994

Qin, N., Yagel, S., Momplaisir, M. L., Codd, E. E., and D’andrea, M. R. (2002). Molecular cloning and characterization of the human voltage-gated calcium channel alpha(2)delta-4 subunit. Mol. Pharmacol. 62, 485-496. doi: 10.1124/ mol.62.3.485

Rees, D. C., Thein, S. L., Osei, A., Drasar, E., Tewari, S., Hannemann, A., et al. (2015). The clinical significance of $\mathrm{K}-\mathrm{Cl}$ cotransport activity in red cells of patients with HbSC disease. Haematologica 100, 595-600. doi: 10.3324/ haematol.2014.120402

Rocha-Gonzalez, H. I., Mao, S., and Alvarez-Leefmans, F. J. (2008). Na+,K+,2Clcotransport and intracellular chloride regulation in rat primary sensory neurons: thermodynamic and kinetic aspects. J. Neurophysiol. 100, 169-184. doi: 10.1152/jn.01007.2007

Rolver, M. G., Elingaard-Larsen, L. O., Andersen, A. P., Counillon, L., and Pedersen, S. F. (2020). Pyrazine ring-based $\mathrm{Na}(+) / \mathrm{H}(+)$ exchanger (NHE) inhibitors potently inhibit cancer cell growth in $3 \mathrm{D}$ culture, independent of NHE1. Sci. Rep. 10:5800.

Russell, J. M. (2000). Sodium-potassium-chloride cotransport. Physiol. Rev. 80, 211-276. doi: 10.1152/physrev.2000.80.1.211

Santoni, G., and Farfariello, V. (2011). TRP channels and cancer: new targets for diagnosis and chemotherapy. Endocr. Metab. Immune Disord. Drug Targets 11, 54-67. doi: 10.2174/187153011794982068

Seo, Y., Lee, H. K., Park, J., Jeon, D. K., Jo, S., Jo, M., et al. (2016). Ani9, a novel potent small-molecule ANO1 inhibitor with negligible effect on ANO2. PLoS One 11:e0155771. doi: 10.1371/journal.pone.0155771

Seo, Y., Ryu, K., Park, J., Jeon, D. K., Jo, S., Lee, H. K., et al. (2017). Inhibition of ANO1 by luteolin and its cytotoxicity in human prostate cancer PC-3 cells. PLoS One 12:e0174935. doi: 10.1371/journal.pone.0174935

Shallat, S., Schmidt, L., Reaka, A., Rao, D., Chang, E. B., Rao, M. C., et al. (1995). NHE-1 isoform of the $\mathrm{Na}+/ \mathrm{H}+$ antiport is expressed in the rat and rabbit esophagus. Gastroenterology 109, 1421-1428. doi: 10.1016/00165085(95) $90626-6$

Shang, L., Hao, J. J., Zhao, X. K., He, J. Z., Shi, Z. Z., Liu, H. J., et al. (2016). ANO1 protein as a potential biomarker for esophageal cancer prognosis and precancerous lesion development prediction. Oncotarget 7, 24374-24382. doi: 10.18632 /oncotarget.8223

Shapiro, J., Van Lanschot, J. J. B., Hulshof, M., Van Hagen, P., Van Berge, M. I., Wijnhoven, B. P. L., et al. (2015). Neoadjuvant chemoradiotherapy plus surgery versus surgery alone for oesophageal or junctional cancer (CROSS): long-term results of a randomised controlled trial. Lancet Oncol. 16, 1090-1098.

Shi, J., Mori, E., Mori, Y., Mori, M., Li, J., Ito, Y., et al. (2004). Multiple regulation by calcium of murine homologues of transient receptor potential proteins TRPC6 and TRPC7 expressed in HEK293 cells. J. Physiol. 561, 415-432.

Shi, Y., Ding, X., He, Z. H., Zhou, K. C., Wang, Q., and Wang, Y. Z. (2009). Critical role of TRPC6 channels in G2 phase transition and the development of human oesophageal cancer. Gut 58, 1443-1450. doi: 10.1136/gut.2009.181735

Shikano, M., Ueda, T., Kamiya, T., Ishida, Y., Yamada, T., Mizushima, T., et al. (2011). Acid inhibits TRPV4-mediated $\mathrm{Ca}(2)(+)$ influx in mouse esophageal epithelial cells. Neurogastroenterol. Motil. 23, 1020-1028, e1497.

Shimizu, H., Shiozaki, A., Ichikawa, D., Fujiwara, H., Konishi, H., Ishii, H., et al. (2014). The expression and role of Aquaporin 5 in esophageal squamous cell carcinoma. J. Gastroenterol. 49, 655-666.

Shiozaki, A., Hikami, S., Ichikawa, D., Kosuga, T., Shimizu, H., Kudou, M., et al. (2018). Anion exchanger 2 suppresses cellular movement and has prognostic significance in esophageal squamous cell carcinoma. Oncotarget 9, 2599326006. doi: $10.18632 /$ oncotarget. 25417

Shiozaki, A., Kudou, M., Ichikawa, D., Shimizu, H., Arita, T., Kosuga, T., et al. (2017). Expression and role of anion exchanger 1 in esophageal squamous cell carcinoma. Oncotarget 8, 17921-17935. doi: 10.18632/oncotarget.14900

Shiozaki, A., Nako, Y., Ichikawa, D., Konishi, H., Komatsu, S., Kubota, T., et al. (2014a). Role of the $\mathrm{Na}(+) / \mathrm{K}(+) / 2 \mathrm{Cl}(-)$ cotransporter $\mathrm{NKCC} 1$ in cell 
cycle progression in human esophageal squamous cell carcinoma. World J. Gastroenterol. 20, 6844-6859.

Shiozaki, A., Takemoto, K., Ichikawa, D., Fujiwara, H., Konishi, H., Kosuga, T., et al. (2014b). The K-Cl cotransporter KCC3 as an independent prognostic factor in human esophageal squamous cell carcinoma. Biomed Res. Int. 2014:936401.

Siddique, I., and Khan, I. (2003). Regulation of Na/H exchanger-1 in gastroesophageal reflux disease: possible interaction of histamine receptor. Dig. Dis. Sci. 48, 1832-1838.

Silva, R. O., Bingana, R. D., Sales, T., Moreira, R. L. R., Costa, D. V. S., Sales, K. M. O., et al. (2018). Role of TRPV1 receptor in inflammation and impairment of esophageal mucosal integrity in a murine model of nonerosive reflux disease. Neurogastroenterol. Motil. e13340. doi: 10.1111/nmo.13340 [Epub ahead of print].

Slepkov, E. R., Rainey, J. K., Sykes, B. D., and Fliegel, L. (2007). Structural and functional analysis of the $\mathrm{Na}+/ \mathrm{H}+$ exchanger. Biochem. J. 401, 623-633. doi: $10.1042 /$ bj20061062

Snow, J. C., Goldstein, J. L., Schmidt, L. N., Lisitza, P., and Layden, T. J. (1993). Rabbit esophageal cells show regulatory volume decrease: ionic basis and effect of pH. Gastroenterology 105, 102-110. doi: 10.1016/0016-5085(93)90015-5

Song, Y., Gao, J., Guan, L., Chen, X., Gao, J., and Wang, K. (2018). Inhibition of ANO1/TMEM16A induces apoptosis in human prostate carcinoma cells by activating TNF-alpha signaling. Cell Death Dis. 9:703.

Spechler, S. J., and Souza, R. F. (2014). Barrett's esophagus. N. Engl. J. Med. 371, 836-845.

Stock, C., and Schwab, A. (2015). Ion channels and transporters in metastasis. Biochim. Biophys. Acta 1848, 2638-2646. doi: 10.1016/j.bbamem.2014.11.012

Suzuki, N., Mihara, H., Nishizono, H., Tominaga, M., and Sugiyama, T. (2015). Protease-activated receptor-2 Up-Regulates transient receptor potential vanilloid 4 function in mouse esophageal Keratinocyte. Dig. Dis. Sci. 60, 35703578. doi: 10.1007/s10620-015-3822-6

Tobey, N. A., Cragoe, E. J., and Orlando, R. C. (1995). HCl-induced cell edema in rabbit esophageal epithelium: a bumetanide-sensitive process. Gastroenterology 109, 414-421. doi: 10.1016/0016-5085(95)90328-3

Tobey, N. A., Koves, G., and Orlando, R. C. (1998). Human esophageal epithelial cells possess an $\mathrm{Na}+/ \mathrm{H}+$ exchanger for $\mathrm{H}+$ extrusion. Am. J. Gastroenterol. 93, 2075-2081. doi: 10.1111/j.1572-0241.1998.00596.x

Tobey, N. A., Reddy, S. P., Khalbuss, W. E., Silvers, S. M., Cragoe, E. J., and Orlando, R. C. (1993). Na(+)-dependent and -independent Cl-/HCO3exchangers in cultured rabbit esophageal epithelial cells. Gastroenterology 104, 185-195. doi: 10.1016/0016-5085(93)90851-3

Toth-Molnar, E., Venglovecz, V., Ozsvari, B., Rakonczay, Z., Varro, A., Papp, J. G., et al. (2007). New experimental method to study acid/base transporters and their regulation in lacrimal gland ductal epithelia. Invest. Ophthalmol. Vis. Sci. 48, 3746-3755.

Tradtrantip, L., Zhang, H., Saadoun, S., Phuan, P. W., Lam, C., Papadopoulos, M. C., et al. (2012). Anti-aquaporin-4 monoclonal antibody blocker therapy for neuromyelitis optica. Ann. Neurol. 71, 314-322. doi: 10.1002/ana. 22657

Ueda, T., Shikano, M., Kamiya, T., Joh, T., and Ugawa, S. (2011). The TRPV4 channel is a novel regulator of intracellular $\mathrm{Ca} 2+$ in human esophageal epithelial cells. Am. J. Physiol. Gastrointest. Liver Physiol. 301, G138-G147.

Vanoni, S., Zeng, C., Marella, S., Uddin, J., Wu, D., Arora, K., et al. (2020). Identification of anoctamin 1 (ANO1) as a key driver of esophageal epithelial proliferation in eosinophilic esophagitis. J. Allergy Clin. Immunol. 145, 239254.e2. doi: 10.1016/j.jaci.2019.07.049

Vashisht, A., Trebak, M., and Motiani, R. K. (2015). STIM and Orai proteins as novel targets for cancer therapy. A review in the theme: cell and molecular processes in cancer metastasis. Am. J. Physiol. Cell Physiol 309, C457-C469.

Venglovecz, V., Hegyi, P., Rakonczay, Z., Tiszlavicz, L., Nardi, A., Grunnet, M., et al. (2011). Pathophysiological relevance of apical large-conductance $\mathrm{Ca}(2)+$-activated potassium channels in pancreatic duct epithelial cells. Gut 60, 361-369. doi: 10.1136/gut.2010.214213
Venglovecz, V., Rakonczay, Z., Ozsvari, B., Takacs, T., Lonovics, J., Varro, A., et al. (2008). Effects of bile acids on pancreatic ductal bicarbonate secretion in guinea pig. Gut 57, 1102-1112. doi: 10.1136/gut.2007.134361

Walker, D., and De Waard, M. (1998). Subunit interaction sites in voltagedependent Ca2+ channels: role in channel function. Trends Neurosci. 21, 148-154. doi: 10.1016/s0166-2236(97)01200-9

Wanajo, A., Sasaki, A., Nagasaki, H., Shimada, S., Otsubo, T., Owaki, S., et al. (2008). Methylation of the calcium channel-related gene, CACNA2D3, is frequent and a poor prognostic factor in gastric cancer. . Gastroenterology 135, $580-590$.

Wu, W., Dong, M. Q., Wu, X. G., Sun, H. Y., Tse, H. F., Lau, C. P., et al. (2012). Human ether-a-go-go gene potassium channels are regulated by EGFR tyrosine kinase. Biochim. Biophys. Acta 1823, 282-289. doi: 10.1016/j.bbamcr.2011.10. 010

Wulamu, W., Yisireyili, M., Aili, A., Takeshita, K., Alimujiang, A., Aipire, A., et al. (2019). Chronic stress augments esophageal inflammation, and alters the expression of transient receptor potential vanilloid 1 and proteaseactivated receptor 2 in a murine model. Mol. Med. Rep. 19, 5386-5396.

Xue, H., Wang, Y., Maccormack, T. J., Lutes, T., Rice, C., Davey, M., et al. (2018). Inhibition of Transient Receptor Potential Vanilloid 6 channel, elevated in human ovarian cancers, reduces tumour growth in a xenograft model. J. Cancer 9, 3196-3207. doi: 10.7150/jca.20639

Yamazato, Y., Shiozaki, A., Ichikawa, D., Kosuga, T., Shoda, K., Arita, T., et al. (2018). Aquaporin 1 suppresses apoptosis and affects prognosis in esophageal squamous cell carcinoma. Oncotarget 9, 29957-29974. doi: 10. 18632/oncotarget.25722

Yu, X., Yu, M., Liu, Y., and Yu, S. (2016). TRP channel functions in the gastrointestinal tract. Semin. Immunopathol. 38, 385-396. doi: 10.1007/s00281015-0528-y

Zeng, C., Vanoni, S., Wu, D., Caldwell, J. M., Wheeler, J. C., Arora, K., et al. (2018). Solute carrier family 9, subfamily A, member 3 (SLC9A3)/sodium-hydrogen exchanger member 3 (NHE3) dysregulation and dilated intercellular spaces in patients with eosinophilic esophagitis. J. Allergy Clin. Immunol. 142, 1843-1855. doi: 10.1016/j.jaci.2018.03.017

Zhang, D. Y., Wang, Y., Lau, C. P., Tse, H. F., and Li, G. R. (2008). Both EGFR kinase and Src-related tyrosine kinases regulate human ether-a-go-go-related gene potassium channels. Cell. Signal. 20, 1815-1821. doi: 10.1016/j.cellsig. 2008.06.006

Zhang, S. S., Wen, J., Yang, F., Cai, X. L., Yang, H., Luo, K. J., et al. (2013). High expression of transient potential receptor $\mathrm{C} 6$ correlated with poor prognosis in patients with esophageal squamous cell carcinoma. Med. Oncol. 30:607.

Zhang, Y., Zhang, Y., Fan, H., Shi, Y., Zhan, C., and Wang, Q. (2017). Study on the role of transient receptor potential C6 channels in esophageal squamous cell carcinoma radiosensitivity. J. Thorac. Dis. 9, 3802-3809. doi: 10.21037/jtd. 2017.09.108

Zhang, Z., Wu, X., Zhang, L., Mao, A., Ma, X., and He, D. (2020). Menthol relieves acid reflux inflammation by regulating TRPV1 in esophageal epithelial cells. Biochem. Biophys. Res. Commun. 525, 113-120. doi: 10.1016/j.bbrc.2020.02.050

Zhu, H., Zhang, H., Jin, F., Fang, M., Huang, M., Yang, C. S., et al. (2014). Elevated Orail expression mediates tumor-promoting intracellular Ca2+oscillations in human esophageal squamous cell carcinoma. Oncotarget 5, 3455-3471. doi: 10.18632/oncotarget.1903

Conflict of Interest: The authors declare that the research was conducted in the absence of any commercial or financial relationships that could be construed as a potential conflict of interest.

Copyright $\odot 2020$ Becskeházi, Korsós, Eröss, Hegyi and Venglovecz. This is an openaccess article distributed under the terms of the Creative Commons Attribution License (CC BY). The use, distribution or reproduction in other forums is permitted, provided the original author(s) and the copyright owner(s) are credited and that the original publication in this journal is cited, in accordance with accepted academic practice. No use, distribution or reproduction is permitted which does not comply with these terms. 